\title{
Biofuel from hydrocracking of Cerbera manghas oil over Ni-Zn/HZSM-5 catalyst
}

Lenny Marlinda $^{1+} \oplus$, Danawati Hari Prajitno ${ }^{2} \oplus$, Achmad Roesyadi ${ }^{2} \oplus$, Ignatius Gunardi ${ }^{2} \oplus$, Yustia Wulandari Mirzayanti ${ }^{3}$, Muhammad Al Muttaqii ${ }^{4} \oplus$ Agus Budianto $^{3}$.

1. University of Jambi, Department of Chemistry, Jambi, Indonesia.

2. Sepuluh Nopember Institute of Technology, Department of Chemical Engineering, Surabaya, Indonesia.

3. Adhi Tama Institute of Technology, Department of Chemical Engineering, Surabaya, Indonesia.

4. Indonesian Institute of Sciences, Research Center for Chemistry, Tangerang Selatan, Indonesia.

+Corresponding author: Lenny Marlinda, Phone: +62 81366079067, Email address: marlindalenny@unja.ac.id

\section{ARTICLE INFO}

Article history:

Received: July 26, 2020

Accepted: October 08, 2021

Published: January 01, 2022
Keywords
1. the non-edible vegetable oil
2. gasoil like-hydrocarbon
3. H-ZSM-5
4. cracking

Section Editor: Assis Vicente Benedetti

ABSTRACT: The effects of reaction temperature on the hydrocarbon composition of biofuel produced in hydrocracking of Cerbera manghas oil with Ni-Zn/HZSM-5 catalyst were investigated. The incipient wetness impregnation method was applied to prepare the Ni-Zn/HZSM-5 catalysts. Furthermore, the properties of catalysts were measured by X-ray diffraction, atomic absorption spectrometry, and nitrogen physisorption. Hydrocracking process was carried out in Parr USA pressure batch reactor at pressure of $20 \pm 5$ bar after flowing $\mathrm{H}_{2}$ for $1 \mathrm{~h}$. The reaction with a catalyst/oil ratio of 1 $\mathrm{g} / 150 \mathrm{~mL}$ proceeded at various temperatures of 350,375 and $400{ }^{\circ} \mathrm{C}$ for $2 \mathrm{~h}$. Gas chromatography-mass spectrometry was used to analyze biofuel. The most abundant hydrocarbon compounds in biofuel were identified as pentadecane and heptadecane (a major diesel fuel compound) with a different amount at different reaction temperatures. It can be said that the

hydrodecarboxylation/decarbony lation routes were the predominant reaction pathways and oxygen removal occurred during hydrocracking. The Cerbera manghas oil can be recommended as a promising biofeed to produce the gasoil as an alternative transportation fuel.

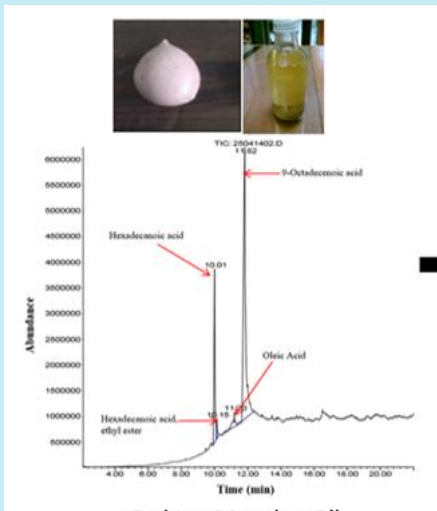

Cerbera Manghas Oil 


\section{Introduction}

When liquid fuel from fossil sources was applied as transportation fuel, the increasing $\mathrm{CO}_{2}$ emission rapidly increased. The use of biofuel will be the right step to achieve zero waste. Hydrocarbon compounds in biofuel are similar with petroleum diesel fuel so that biofuel can be a substitute for diesel fuel. Development of biofuel production technology continues to evolve concurrently with the exploration of vegetable oil as raw materials while maintaining the sustainability of food security. Biofuel was already used both in pure form and blending is fatty acid methyl esters (FAMEs), also known as oxygenated biofuels, as reported by Romero et al. (2015). The oxygenated biofuel is also known as biodiesel. Bio-oil and biodiesel can be grouped as biofuels, which are environmentally friendly alternative fuels that can replace petroleum. However, they both have different hydrocarbon compositions. Biodiesel contains hydrocarbon compounds with oxygen atoms in esters. The bio-oil contains a large number of organic compounds, namely alkanes, aromatic hydrocarbons, and phenol derivatives. Small amounts of ketones, esters, ethers, sugars, amines and alcohols with an $\mathrm{H} / \mathrm{C}$ molar ratio higher than 1.5 were identified in bio-oil (Lu et al., 2009; Wu et al., 2009). The method of high thermal decomposition (pyrolysis) without the addition of $\mathrm{O}_{2}$ /air was used to produce it (Isahak et al., 2012).

Fatty acid methyl esters or biodiesel were produced by transesterification of the extracted seed-derived vegetable oils (e.g., rapeseed oil, cotton oil, palm oil, soybean oil, and jatropha seed) and methanol. It was still having the properties that have not been profitable for diesel engines (Ayodele et al., 2015; Chen et al., 2016; Kim et al., 2013; Pinto et al., 2013; Šimáček et al., 2009; Wang et al., 2014). Some phenomena, such as blockages in some parts of the fuel system, the appearance of deposit and sludge on the storage system, corrosion on metal parts due to the relatively high-water solubility in FAMEs, causing swelling of rubber components, can be a factor causing engine damage (Kim et al., 2013; Šimáček et al., 2009; 2011). The limiting properties of FAMEs for the application directly as a fuel in vehicle engines are low energy density, poor oxidation stability of FAMEs (Ayodele et al., 2015; Chen et al., 2016; Kim et al., 2013), which is caused by excess oxygen incorporated in carboxyl or carbonyl groups (Chen et al., 2016; Kim et al., 2013; Romero et al., 2015; Wang et al., 2014), the high value of viscosity and pour point, poor calorific value (Wang et al., 2014), poor storage stability, and glycerol byproduct menace (Ayodele et al., 2015). Therefore,
FAMEs composed of the different chemical compounds can damage the engine combustion and reduce the engine performance (Pinto et al., 2013).

The other method for converting vegetable oil to biofuel is hydrocracking applied before in crude oil refinery unit with heterogeneous catalyst. Some of the catalysts have been applied in vegetable oils processing into biofuel through the catalytic cracking and hydrocracking. The CoMoS and NiMoS catalysts (Kim et al., 2013; Zhang et al., 2014), NiMo/ZSM-5-alumina (Ishihara et al., 2014), $\mathrm{CoMo} / \gamma-\mathrm{Al}_{2} \mathrm{O}_{3}$ (Bezergianni et al., 2014; Pinto et al., 2014; Rasyid et al., 2015), ultrastable Y (USY) zeolite (Li et al., 2014), HZSM-5 based catalyst, e.g., Ni or Zn supported on HZSM-5 (Budianto et al., 2014a; Roesyadi et al., 2013), Pt, Pd, or Au supported on H-ZSM-5 (Budianto et al., 2014b), NiZn/HZSM-5 (Prajitno et al., 2015), Ni or Ga supported on HZSM-5 (Tamiyakul et al., 2016) were typical catalysts for catalytic cracking or hydrocracking of triglycerides to obtain biofuel. However, the mesoporous zeolite is preferred to support diffusion of the reactants and produce alkane isomers with relatively high yields (Chen et al., 2016).

Wang et al. (2014) deoxygenated soybean oil with the Ni/HZSM-5 catalyst through a single-step hydrotreatment process combining deoxygenation of fatty acid into $\mathrm{n}$-paraffin as the main hydrocarbon product and isomerization to obtain isoparaffin. Apparently, catalytic activity of Ni/SAPO-11 is higher than Ni/HZSM-5 catalyst in a single-step hydrotreatment process based on the amount of $n$ paraffin produced and oxygenated compounds remaining. Hierarchical pore structure becomes a good solution to obtain the size of micropores-mesopores on HZSM-5 in an effort to increase the activity of catalyst, as suggested by Liu et al. (2015). With the Ni/HZSM-5 catalyst, Chen et al. (2016) promoted long-chain unsaturated FAMEs through one-step catalytic hydroprocessing (including deoxygenation and decarboxylation or decarbonylation, followed by isomerization). With the Ni/HZSM-5 catalyst (silica to alumina ratio of 25) and metal loading of $10 \mathrm{wt} . \%$, it was found that high selectivity of C5-C18 n-paraffins and isomerization selectivity were 88.2 and $27.0 \%$, respectively (Chen et al., 2016). In this case, changes in the $\mathrm{Si} / \mathrm{Al}$ ratio affect the acidity of the zeolite and have an impact on variations in the composition of hydrocarbon compounds in the liquid product. Based on this, it is remarkably interesting for impregnating double promoter of $\mathrm{Ni}$ and $\mathrm{Zn}$ metal into HZSM-5 zeolite. This prepared catalyst is expected to improve the degree of triglycerides hydrocracking when compared to using one active metal only. 
So far, the fuel produced has characteristics which can maintain the machine durability and do not require substantial modification of conventional machines. Problems resulted from the use of FAMEs are resolved through the removal of oxygen atoms in the fatty acid by reaction hydrocracking, i.e., hydrodecarbonylation/decarboxylation (HDC) and hydrodeoxygenation (HDO) (Arun et al., 2015; Ishihara et al., 2014; Kim et al., 2013; Silva and Sousa, 2013; Zhang et al., 2014) and then followed by isomerization. Kim et al. (2013) stated it is especially important to understand and control the reactions (i.e., dehydrogenation, isomerization, cyclization, and aromatization) related to the oxygen removal on triglycerides in hydrocracking process to produce biofuel with fuel properties (including cloud point and cetane number). The fuel properties were influenced by hydrocarbon composition, such as (normal, iso-) paraffin, olefins, cycloparaffin, and aromatic. These reaction routes may lead to the formation of hydrocarbons such as n-paraffins, isoparaffins, cycloparaffins, aromatics, and olefins (Kim et al., 2013; Ishihara et al., 2014; Zhang et al., 2014). It is very important to keep the hydrogen partial pressure not too high during the hydrocracking process because it resulted in a low yield of hydrocarbons, as stated by Santillan-Jimenez and Crocker (2012).

Biofuel derived from nonedible vegetable oil through hydrocracking process is becoming a promising renewable alternative fuel in sustainable energy production. The candlenut, jatropha, rubber seed, Cerbera manghas seed, Calophyllum inophyllum have been used as sources of nonedible vegetable oils. Seeds from these plants contain toxic substances which humans cannot consume, e.g., cerberin is found in Cerbera manghas seed. Carlier et al. (2014) also reported that dry seeds of Cerbera manghas contained a number of compounds: cerberin, deacetyltanghinin, neriifolin, and tanghinin. Cerbera manghas trees, part of the ecosystem of the mangrove forests, can reach a height of $12 \mathrm{~m}$. These plants can be found as urban greening plants. Their seeds contained a high level of crude Cerbera oil of approximately 46-64\%.

In this work, the influence of reaction temperature for two different composition ratios of metals impregnated on HZSM-5 on the hydrocarbon composition in biofuels by hydrocracking of Cerbera manghas oil is discussed. It is expected that characteristics of hydrocarbon composition in the biofuel produced are similar to petroleum-based fuels. Based on gas chromatography-mass spectrometry (GCMS) analysis, decarboxylation/decarbonylation occurred during hydrocracking was also discussed.

\section{Materials and Methods}

\subsection{Extraction of Cerbera manghas}

Dried fruits of Cerbera manghas were obtained from plant that grows in Keputih, Surabaya, Indonesia. It is also known as Bintaro plant in Java Island. Cerbera manghas oil was extracted from seeds through the process steps that according to previous literature, as shown in Fig. 1 (Roesyadi, 2016). At first the fruit was split and the seeds were removed from the fruit. These seeds were cleaned from the skin and obtained white oval-shaped seeds. Furthermore, the seeds were dried in the sun for 7 days. After drying, the dry seeds were chopped and extracted by hydraulic press to produce oil. Oil was stored in an airtight container to prevent oxidation, which can increase free fatty acid levels. Cerbera manghas oil from the hydraulic extraction process was obtained as much as $2.5 \mathrm{~L}$ from $6 \mathrm{~kg}$ of seeds. It can be said that $2 \mathrm{~kg}$ of Bintaro seeds produce about $0.8 \mathrm{~L}$ of oil. Figure 2 specify the different conditions of the seed and the obtained oil.

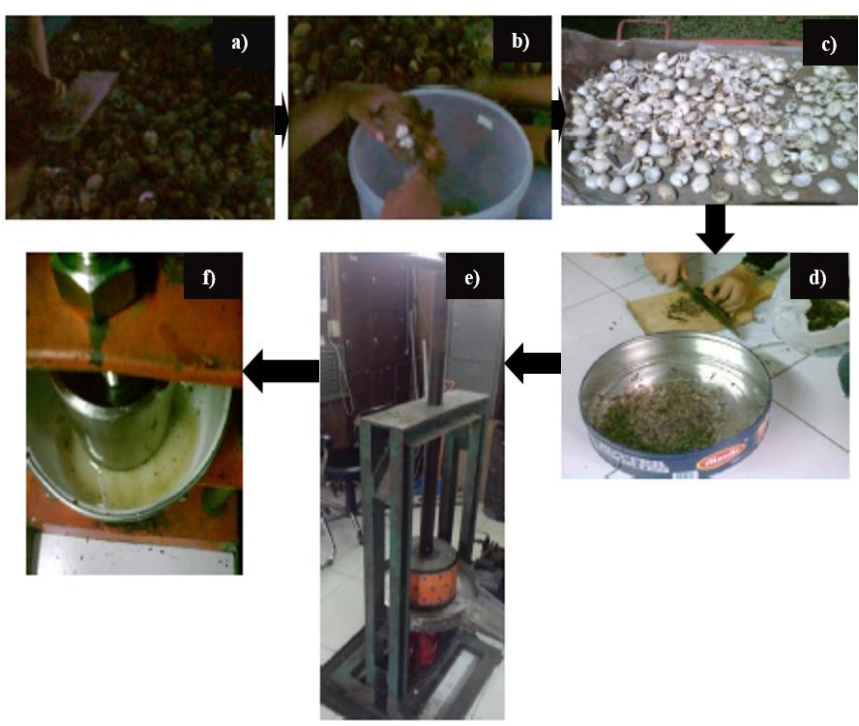

Figure 1. Extraction process of Cerbera manghas seeds. (a) the fruit was split into two parts, (b) the seeds were removed from the fruit, (c) the seeds were dried in the sun, (d) the dry seeds were chopped, finally $(\mathbf{e}, \mathbf{f})$ the seeds were extracted by hydraulic press.

Source: Adapted from Roesyadi (2016). 


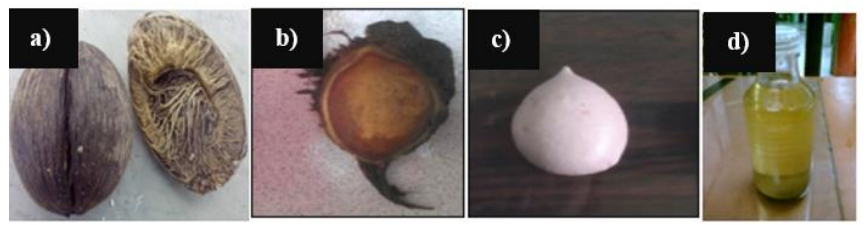

Figure 2. Different condition of Cerbera manghas fruit and the obtained oil. (a) a dried fruit, (b) seed with skin, (c) white oval-shaped seeds seed, (d) oil.

Source: Adapted from Roesyadi (2016).

\subsection{Catalyst preparation}

ZSM-5 zeolite in ammonium form (CBV 8014, $\mathrm{SiO}_{2} / \mathrm{Al}_{2} \mathrm{O}_{3}$ ratio of 25 , surface area of $400 \mathrm{~m}^{2} \mathrm{~g}^{-1}, \mathrm{Na}_{2} \mathrm{O}$ of 0.05 wt.\%) was provided from Zeolyst International. Meanwhile, $\mathrm{Ni}\left(\mathrm{NO}_{3}\right)_{2} \cdot 6 \mathrm{H}_{2} \mathrm{O}$ and $\mathrm{Zn}\left(\mathrm{NO}_{3}\right)_{2} \cdot 6 \mathrm{H}_{2} \mathrm{O}$ as the metal precursor were obtained from Merck with $98 \%$ purity. The calcination process on $\mathrm{NH}_{4}-\mathrm{ZSM}-5$ zeolite was applied to obtain HZSM-5 zeolite at temperature of $550{ }^{\circ} \mathrm{C}$ for $5 \mathrm{~h}$ (Sartipi et al., 2013). By incipient wetness impregnation method (Haber et al., 1995; Marlinda et al., 2016; Sartipi et al., 2013), HZSM-5 after calcined was impregnated with nickel and zinc to obtain Ni-Zn/HZSM-5 catalyst. Before impregnation, the HZSM-5 zeolite was dried overnight at a temperature of $120{ }^{\circ} \mathrm{C}$. The amount of aqueous metal solutions was calculated according to the total pore volume of HZSM-5 as support, which was obtained from Brunauer-Emmett-Teller (BET) analysis, as shown in Table 1. After preparing aqueous metal solutions, firstly the amount of aqueous $\mathrm{Ni}\left(\mathrm{NO}_{3}\right)_{2} \cdot 6 \mathrm{H}_{2} \mathrm{O}$ solution of $1.81 \mathrm{~mol} \mathrm{~L}^{-1}$ was sprayed slowly to HZSM5 zeolite while stirring and then kept overnight in a desiccator. Finally, this catalyst was dried at $120^{\circ} \mathrm{C}$ for $12 \mathrm{~h}$. Furthermore, in the same way as before, the amount of aqueous $\mathrm{Zn}\left(\mathrm{NO}_{3}\right)_{2} \cdot 6 \mathrm{H}_{2} \mathrm{O}$ solution of 1.62 mol L ${ }^{-1}$ was sprayed slowly to HZSM-5 zeolite while stirring. Before drying at temperature of $120^{\circ} \mathrm{C}$ for 12 $\mathrm{h}$, the catalyst was kept overnight in a desiccator. Catalysts containing $\mathrm{Ni}$ and $\mathrm{Zn}$ salt solution were calcined with air at temperature of $400{ }^{\circ} \mathrm{C}$ for $2 \mathrm{~h}$. After calcination, active metal usually exists as a form of metal oxide (Kim et al., 2013; Romero et al., 1998). The metallic phases of $\mathrm{Ni}$ and $\mathrm{Zn}$ were obtained by reducing the metal oxides under flowing hydrogen at a temperature of $450{ }^{\circ} \mathrm{C}$ for $3 \mathrm{~h}$. By atomic absorption spectrometry, the metal content was 5.43 wt.\% of $\mathrm{Ni}$ and $1.23 \mathrm{wt} . \%$ of $\mathrm{Zn}$ of the total catalyst weight. The catalyst is denoted as $\mathrm{Ni}(5.43 \%)-\mathrm{Zn}(1.23 \%) / \mathrm{HZSM}-5$ catalyst. Other prepared catalyst is $\mathrm{Ni}(5.42 \%)$ $\mathrm{Zn}(1.11 \%) / \mathrm{HZSM}-5$.

Table 1. The characterization of H-ZSM-5 and Ni-Zn/HZSM-5 catalyst.

\begin{tabular}{|c|c|c|c|c|c|c|c|c|c|c|}
\hline \multirow[t]{2}{*}{ Catalyst } & \multicolumn{3}{|c|}{ Surface area $\left(\mathrm{m}^{2} \mathrm{~g}^{-1}\right)$} & \multicolumn{3}{|c|}{ Volume $\left(\mathrm{cm}^{3} \mathrm{~g}^{-1}\right)$} & \multirow{2}{*}{$\begin{array}{c}D^{f} \\
(\mathbf{n m})\end{array}$} & \multicolumn{2}{|c|}{$\begin{array}{c}\text { Actual metal } \\
\text { content' }^{\mathrm{g}}(\text { wt. \%) }\end{array}$} & \multirow[t]{2}{*}{ References } \\
\hline & Total $^{\mathbf{a}}$ & Micro & Meso & Total $^{\mathrm{c}}$ & Micro $^{d}$ & Meso $^{\mathrm{e}}$ & & $\mathrm{Ni}$ & $\mathrm{Zn}$ & \\
\hline HZSM-5 & 362.77 & 315.13 & 47.64 & 0.245 & 0.156 & 0.089 & 2.709 & - & - & Present study \\
\hline $\begin{array}{l}\mathrm{Ni}(5.43 \%)- \\
\mathrm{Zn}(1.23 \%) / \mathrm{HZSM}-5\end{array}$ & - & - & - & - & - & - & - & 5.43 & 1.23 & Present study \\
\hline $\begin{array}{l}\mathrm{Ni}(5.42 \%)- \\
\mathrm{Zn}(1.11 \%) / \mathrm{HZSM}-5\end{array}$ & 246.06 & 205.52 & 40.54 & 0.191 & 0.101 & 0.090 & 3.109 & 5.42 & 1.11 & $\begin{array}{c}\text { (Roesyadi et } \\
\text { al., 2016) }\end{array}$ \\
\hline
\end{tabular}

$\mathrm{a}=$ total surface area BET; $\mathrm{b}=$ the surface area mesoporous and microporous obtained from the $\mathrm{t}$-plot; $\mathrm{c}=$ total pore volume; $\mathrm{d}$

$=$ micropore volume obtained from the $\mathrm{t}-$ plot; $\mathrm{e}=$ mesoporous volume $=\mathrm{V}_{\text {meso }}=\mathrm{V}_{\text {total }}-\mathrm{V}_{\text {mikro }} ; \mathrm{f}=$ average pore diameter; $\mathrm{g}=$ atomic absorption spectrometry (AAS) analysis.

Source: Elaborated by the authors using data from Roesyadi et al. (2016).

\subsection{Characterization of catalyst}

The various techniques used to characterize catalysts were X-ray diffraction (XRD), atomic absorption spectrometry (AAS) and $\mathrm{N}_{2}$ adsorption-desorption. The metal contents of $\mathrm{Ni}$ dan $\mathrm{Zn}$ were confirmed with AAS. In principle, the distribution of metal on ZSM-5 is influenced by the preparation method used (Chen et al., 2015). X-ray diffraction was applied to identify phase analysis and the Ni-Zn/HZSM-5 catalyst crystallinity. $\mathrm{X}$-ray diffraction patterns of the solid catalyst (Phillip $\mathrm{X}$-Pert diffractometer with $\mathrm{Cu}$ radiation $\mathrm{K} \alpha$ ) were collected from $2 \theta$ of $5-90^{\circ}$ to identify the peak of crystalline zeolite ZSM-5. The existence of the crystalline phase of $\mathrm{NiO}, \mathrm{ZnO}, \mathrm{Ni}$ and $\mathrm{Zn}$ particles was confirmed from the diffraction patterns recorded on $2 \theta$ $=30-80^{\circ}$.

The catalyst surface area was measured by BET calculation on Quantachrome NovaWin Version 10.0 according to the adsorption data with the relative pressure $(\mathrm{P} / \mathrm{Po})$ in range from 0.095 to 0.297 through the recording process of isotherm BET on five points. Before the measurement of nitrogen adsorption and desorption isotherms at a temperature of $77 \mathrm{~K}$, the sample was outgassed for $16 \mathrm{~h}$ at $300{ }^{\circ} \mathrm{C}$. The pore size 
distributions were calculated using adsorption model of Barrett-Joyner-Halenda (BJH). Micropores volumes were obtained from the t-plot analysis. Total pore volumes were obtained according to the amount of nitrogen adsorbed at relative pressure about 0.99034 . Mesoporous volumes were obtained from the reduction of the total pore volume by the volume of micropore.

\subsection{Hydrocracking reaction}

Hydrocracking reactions were carried out in the Parr USA pressure batch reactor equipped with a mechanical stirrer. Cerbera manghas oil of $150 \mathrm{~mL}$ and catalysts of $1 \mathrm{~g}$ were transferred in the reactor. To remove air, nitrogen was flowed into the reactor at least $30 \mathrm{~min}$ for purging. Depending on temperature condition, reaction pressure was changed between 15 and 25 bar after flowing $\mathrm{H}_{2}$ for at least $1 \mathrm{~h}$, as reported in previous study (Marlinda et al., 2016). The reaction proceeded at various temperatures, i.e., 350,375 and $400{ }^{\circ} \mathrm{C}$ for $2 \mathrm{~h}$. After a reaction time was reached, the reactor temperature was allowed to reach room temperature. Furthermore, biofuel was analyzed by GC-MS, i.e., Agilent HP 6890 GC equipped with a capillary column, model Agilent 19091S-433 (HP-5MS, phenylmethylsiloxane of $5 \%$ ). The column dimensions used have an internal diameter of $0.25 \mathrm{~mm}$, film thickness of $0.25 \mu \mathrm{m}$ and a length of $30 \mathrm{~m}$. All hydrocarbon components are identified using the Wiley275 and NIST02 mass spectral library of data. Based on GC-MS analysis, it is possible to estimate the relative percentages of hydrocarbon composition and distribution of products to their carbon numbers. According to Barrón et al. (2011), hydrocarbon compounds (including n-paraffin, isoparaffin, cycloparaffin, aromatic, olefin) were grouped in gasoline-like hydrocarbon (C5-C9), kerosene-like hydrocarbon (C10-C13), and gasoil-like hydrocarbon (C14-C22).

\section{Results and discussion}

\subsection{Oil characterization}

The clear yellow color of Cerbera manghas oil without purification was analyzed by GC-MS. Table 2 indicated that the most abundant compound in Cerbera manghas oil is oleic acid at 77.76 area\%, which agrees with that obtained by Marlinda et al. (2016). Oleic acid is also the largest constituent of Calophyllum inophyllum oil, Jatropha curcas oil (Chuah et al., 2016) and Pongamia pinnata oil (Dwivedi and Sharma, 2015), as much as $39.8 \pm 0.4,51.2 \pm 0.6$ and 65.3 wt. $\%$, respectively.

Table 2. Compounds of Cerbera manghas oil tested by GC-MS.

\begin{tabular}{|l|c|c|c|}
\hline Compound & Chemical name & Molecular formula & Content (\%) \\
\hline Palmitic acid; C16:0 & Hexadecanoic acid & $\mathrm{C}_{15} \mathrm{H}_{31} \mathrm{COOH}$ & 20.29 \\
\hline Oleic acid; $\mathrm{C} 18: 1$ & 9-Octadecenoic acid & $\mathrm{C}_{17} \mathrm{H}_{33} \mathrm{COOH}$ & 77.76 \\
\hline Ethyl palmitate & Hexadecanoic acid, ethyl ester & $\mathrm{C}_{18} \mathrm{H}_{36} \mathrm{O}_{2}$ & 1.95 \\
\hline
\end{tabular}

Source: Elaborated by the authors using data from Prajitno et al. (2015).

\subsection{Catalysts characterization}

Some different techniques were used to obtain the textural properties and metal content of the NiZn/HZSM-5 catalyst. Figure 3 shows the type of adsorption isotherms classified by International of Pure Applied Chemistry (IUPAC) for HZSM-5 and $\mathrm{Ni}$ Zn/HZSM-5 catalyst. It was clear that a combined pattern of type I and type IV was exhibited in Fig. 3b. The type of microporous solids owned by HZSM- 5 is type I isotherm, as shown in Fig. 3a. It shows an initial curve that rises sharply at very low relative pressure, as reported in previous studies (Hao et al., 2012; Sartipi et al., 2013; Wang et al., 2013). The mesopores and the pore size distribution calculated from the sorption isotherm can be called hysteresis. The presence of hysteresis exhibited with type IV isotherm was seen on high relative pressure of 0.65 towards 0.85 , at which $\mathrm{N}_{2}$ desorption does not pass through the adsorption original path (Hao et al., 2012; Vitale et al., 2013; Wang et al., 2013). Nickel and zinc impregnated on support can create mesoporous sites in catalyst, so that bulky molecules can diffuse easily to the pores of catalyst, as reported in previous studies (Hao et al., 2012; Vitale et al., 2013; Wang et al., 2013). 

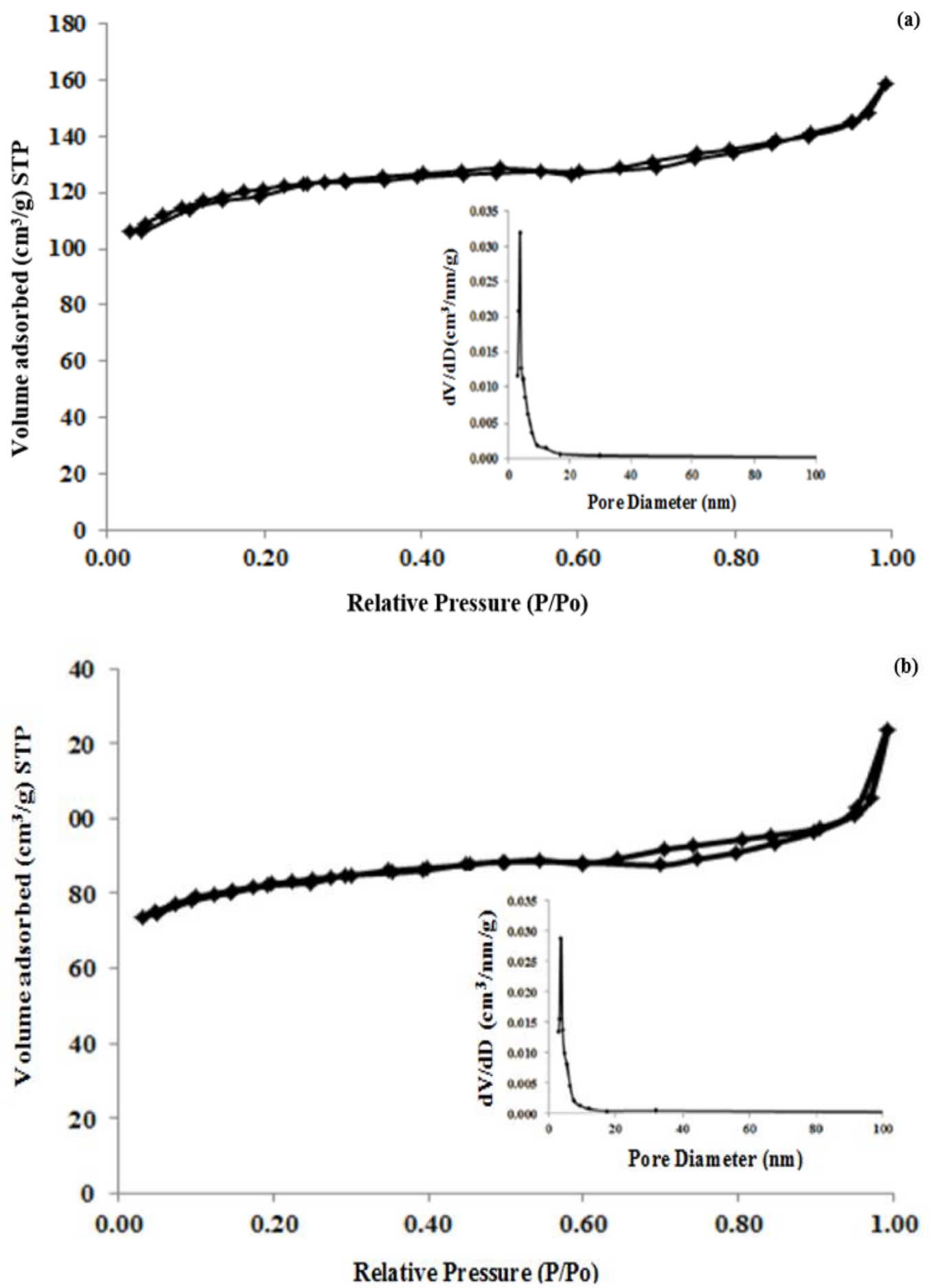

Figure 3. Nitrogen adsorption and desorption and BJH pore size distribution of catalyst. (a) HZSM-5; (b) Ni(5.42\%)$\mathrm{Zn}(1.11 \%) / \mathrm{HZSM}-5$ catalyst.

The pore size distributions of the two types of the catalyst were centered at $3.8 \mathrm{~nm}$. However, the slightly narrower pore size distribution and lower peak height were seen on Ni-Zn impregnated on HZSM-5. Reduction of peak height on the catalyst showed that the presence of $\mathrm{Ni}$ and $\mathrm{Zn}$ had a considerable influence on the pore structure of HZSM-5. Both of the catalysts have a mesoporous structure as the result of the interparticle voids. This pore structure will greatly affect the increase of reactivity of the catalysts, as reported by Wang et al. (2013). 
Table 1 shows that micropores volume decreased from 0.156 to $0.101 \mathrm{~cm}^{3} \mathrm{~g}^{-1}$, while pore diameter increased from 2.709 to $3.109 \mathrm{~nm}$ after $\mathrm{Ni}-\mathrm{Zn}$ metals were impregnated on HZSM-5. Nevertheless, Chen et al. (2016) stated that the internal nickel particles can inhibit the nitrogen molecules into the pore by blocking the micropores of HZSM-5. However, the increase of pore diameter and the presence of mesopores size distribution indicated that fatty acids had a significant probability to diffuse into the pores successfully and react on the active sites. According to Bockisch (1998), assuming a typical triglyceride molecule to have a spherical form, its diameter would be $1.5 \mathrm{~nm}$. Therefore, if the fatty acids cannot diffuse and react with the active sites located in micropores channel, then these fatty acids will diffuse and react with the active sites located in mesopores channel. While the actual metals content obtained were shown in Table 1.

$\mathrm{X}$-ray diffraction data of catalyst system shows that the full diffractograms were recorded in the range $2 \theta^{\circ}$ of 5-90 to see the diffraction peak of $\mathrm{NiO}, \mathrm{ZnO}, \mathrm{Ni}$ and $\mathrm{Zn}$ in the catalyst samples. The characteristic of diffraction peaks of commercial HZSM-5, as shown in Fig. 4a, located at $2 \theta$ of 7.9, 8.8, 23.09, 23.31, 23.69, 23.9 and $24.4^{\circ}$, which indicated a structure type mordenite framework inverted (MFI), as reported by a previous study (Marlinda et al., 2016). As shown in Fig. $4 \mathrm{~b}$ and c, diffractograms of catalyst used for the hydrocracking on Cerbera manghas oil were almost similar to those of commercial HZSM-5.
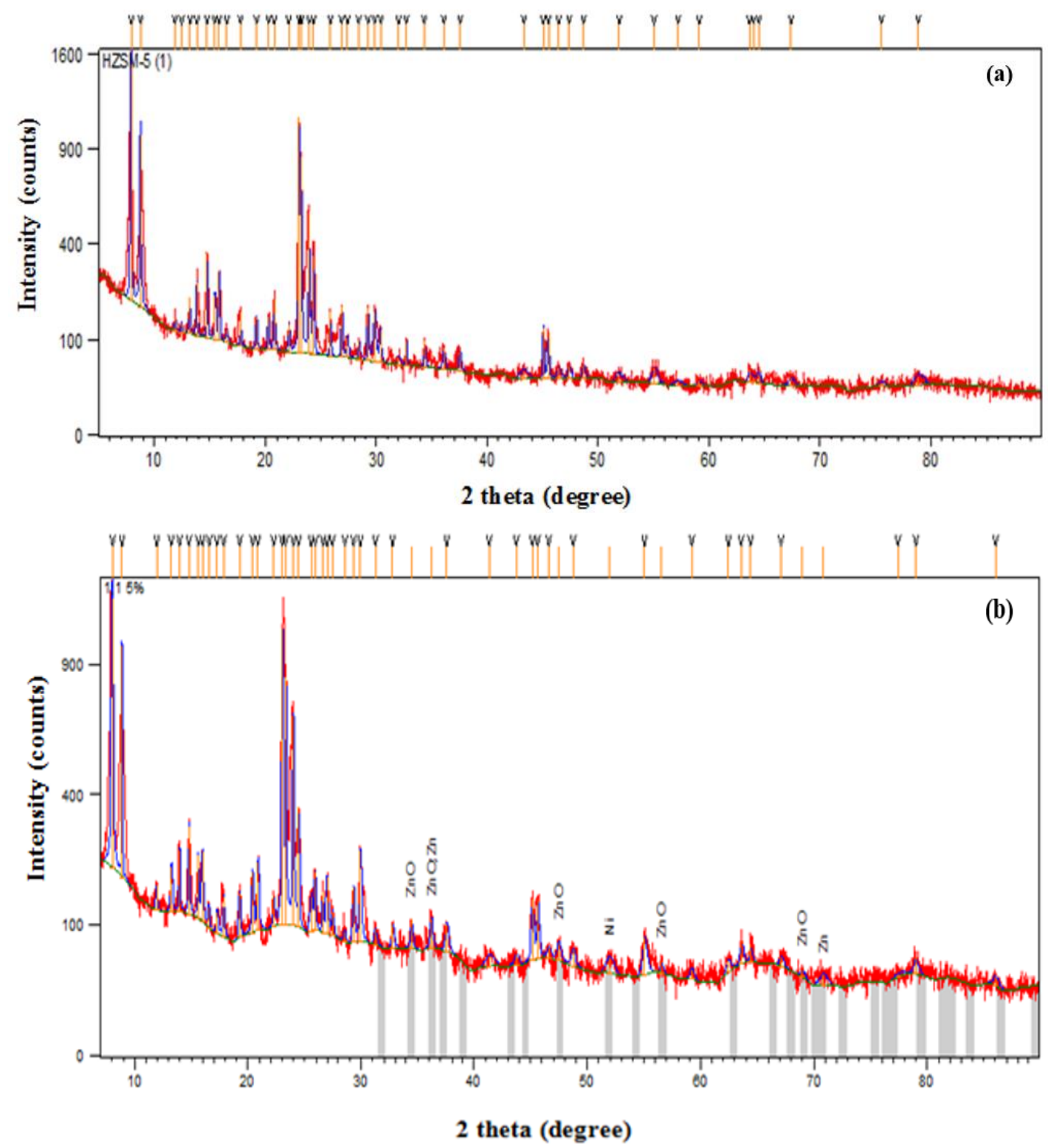


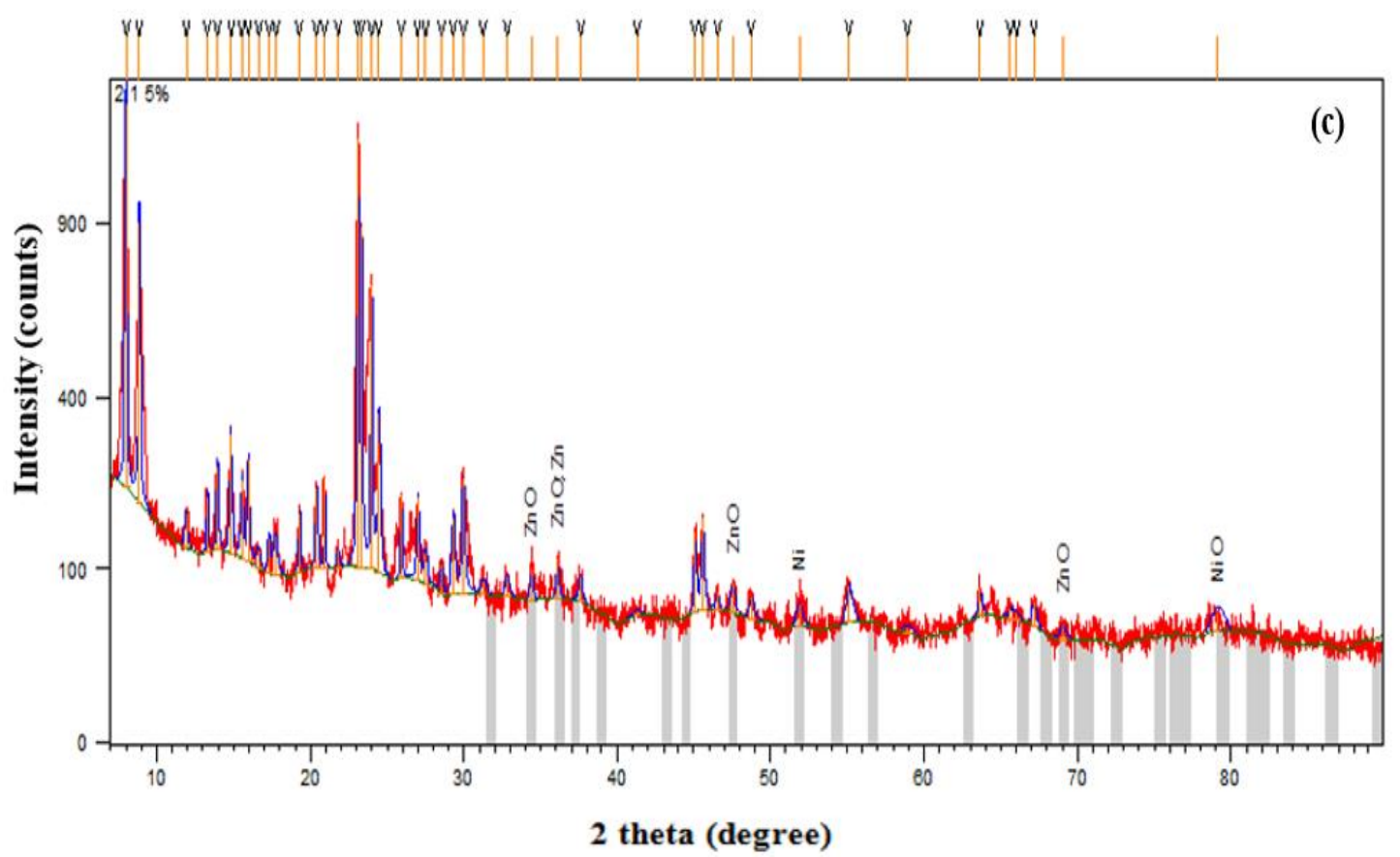

Figure 4. X-ray diffraction pattern of catalysts. (a) Commercial HZSM-5 after calcined (Marlinda et al., 2016), (b) $\mathrm{Ni}(5.43 \%)-\mathrm{Zn}(1.23 \%) / \mathrm{HZSM}-5$ catalyst, (c) Ni(5.42\%)-Zn(1.11\%)/HZSM-5 catalyst.

After impregnation with $\mathrm{Ni}-\mathrm{Zn}$, the HZSM-5 framework structure was almost unchanged, but only the intensity of each diffraction peak decreased (Chen et al., 2016; Niu et al., 2014; Wang et al., 2013). Figure $4 \mathrm{~b}$ shows that a small intensity diffraction peak of $\mathrm{ZnO}$ crystallites was observed at $2 \theta$ of $34.55,36.32,47.56$, 56.66 and $69.08^{\circ}$. The $\mathrm{Zn}$ and $\mathrm{Ni}$ particles were also observed at $2 \theta$ of 70.94 and $52.06^{\circ}$ with low intensity, respectively. While the presence of $\mathrm{NiO}$ crystallite was not found. Figure $4 \mathrm{c}$ shows that a small peak diffraction intensity of $\mathrm{ZnO}$ crystallites were observed at $2 \theta$ of $34.53,36.19,47.58$ and $69.10^{\circ}$. $\mathrm{NiO}$ crystallite and $\mathrm{Ni}$ particle were observed at $2 \theta$ of 79.23 and $51.96^{\circ}$ with low intensity, respectively. While the presence of $\mathrm{Zn}$ metal was not detected. When incipient wetness impregnation method was applied by means of physical mixing, diffraction peak for $\mathrm{ZnO}$ was obtained at $2 \theta$ of $36.21^{\circ}$, as observed by Niu et al. (2014). In principle, the reduction of $\mathrm{ZnO}$ and $\mathrm{NiO}$ crystallites with hydrogen will lead to the formation of proton ions $\left(\mathrm{H}^{+}\right)$, as the Bronsted acid. As reported by Chen et al. (2016), after reduction of $\mathrm{NiO}$ with hydrogen, proton ion $\left(\mathrm{H}^{+}\right)$ was formed $\left(\mathrm{Ni}^{2+}+\mathrm{H}_{2} \rightarrow \mathrm{Ni}+2 \mathrm{H}^{+}\right)$so that the catalysts which contained Bronsted acid sites (weak strength sites) have contributed to direct isomerization reaction. While Lewis acid sites (strong acid sites) may direct the ability of cracking.

\subsection{Biofuel analysis}

Biofuel produced from hydrocracking of Cerbera manghas oil at a temperature of $400{ }^{\circ} \mathrm{C}$ with a Ni$\mathrm{Zn}(2 \%) / \mathrm{HZSM}-5$ catalyst and Ni-Zn(4\%)/HZSM-5 (Prajitno et al., 2015) still contained many carboxylic acids and compounds containing more oxygen, i.e., 9octadecenal in the range of 5.35-6.11\% and ethenone in the range of $0.20-0.37 \%$. Table 3 shows that olefins are found in very small quantities while the n-paraffins and cycloparaffins can only be obtained from catalyst with metal loading of $4 \%$. It indicated that the metals impregnated on HZSM-5 have not been able to hydrogenate fatty acid. The GC-MS spectra of biofuel is shown in Fig. 5. 


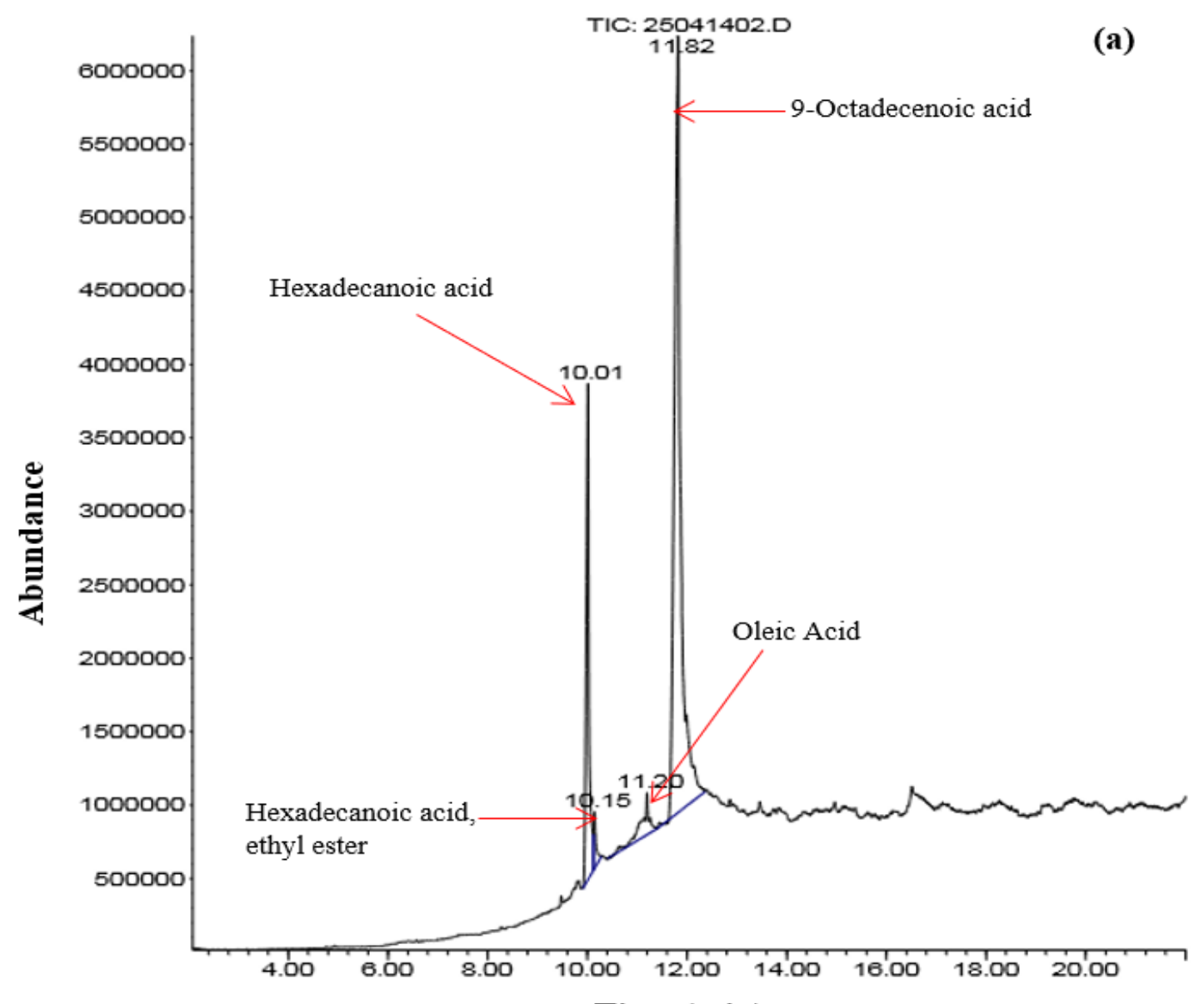

Time (min)

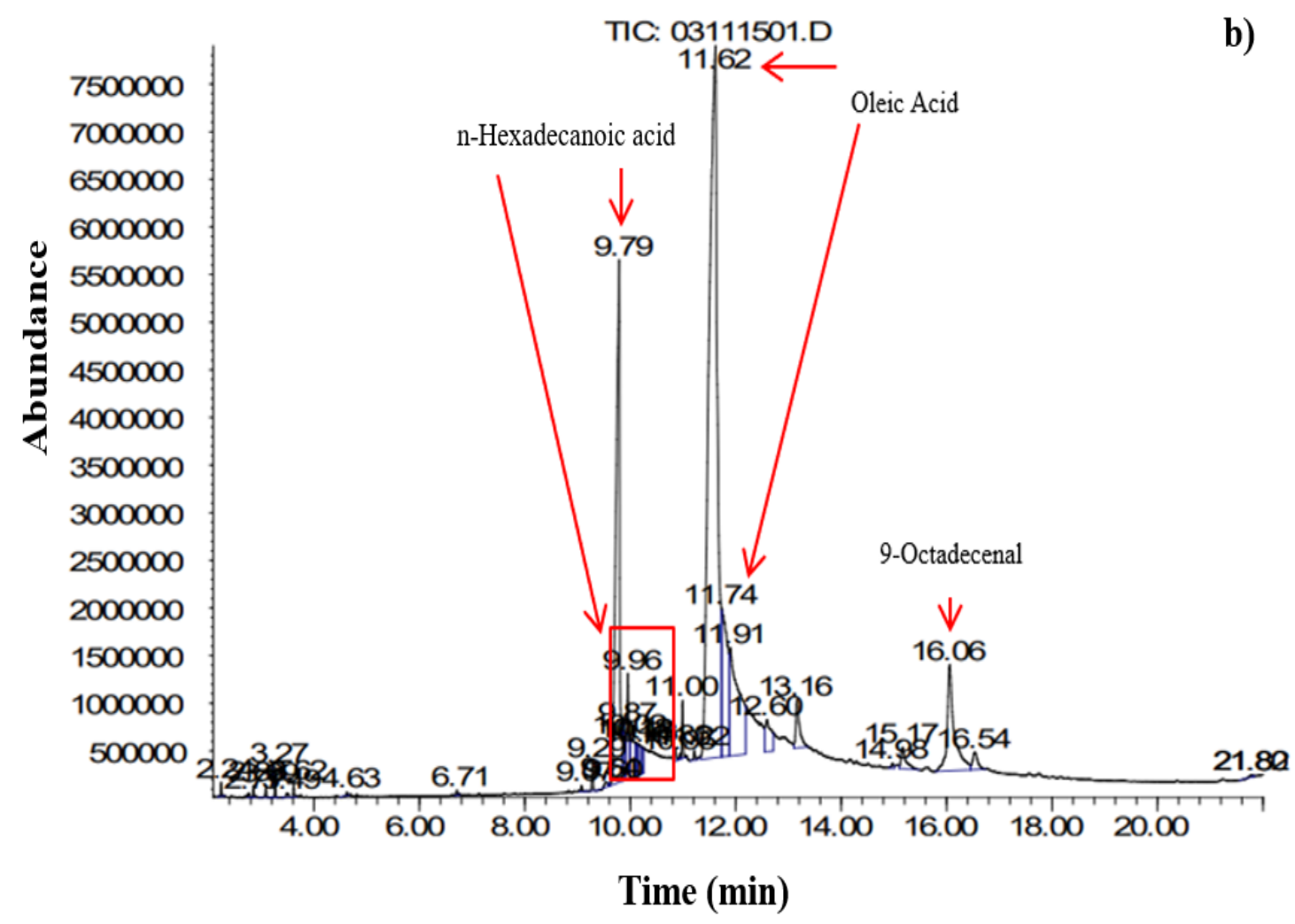




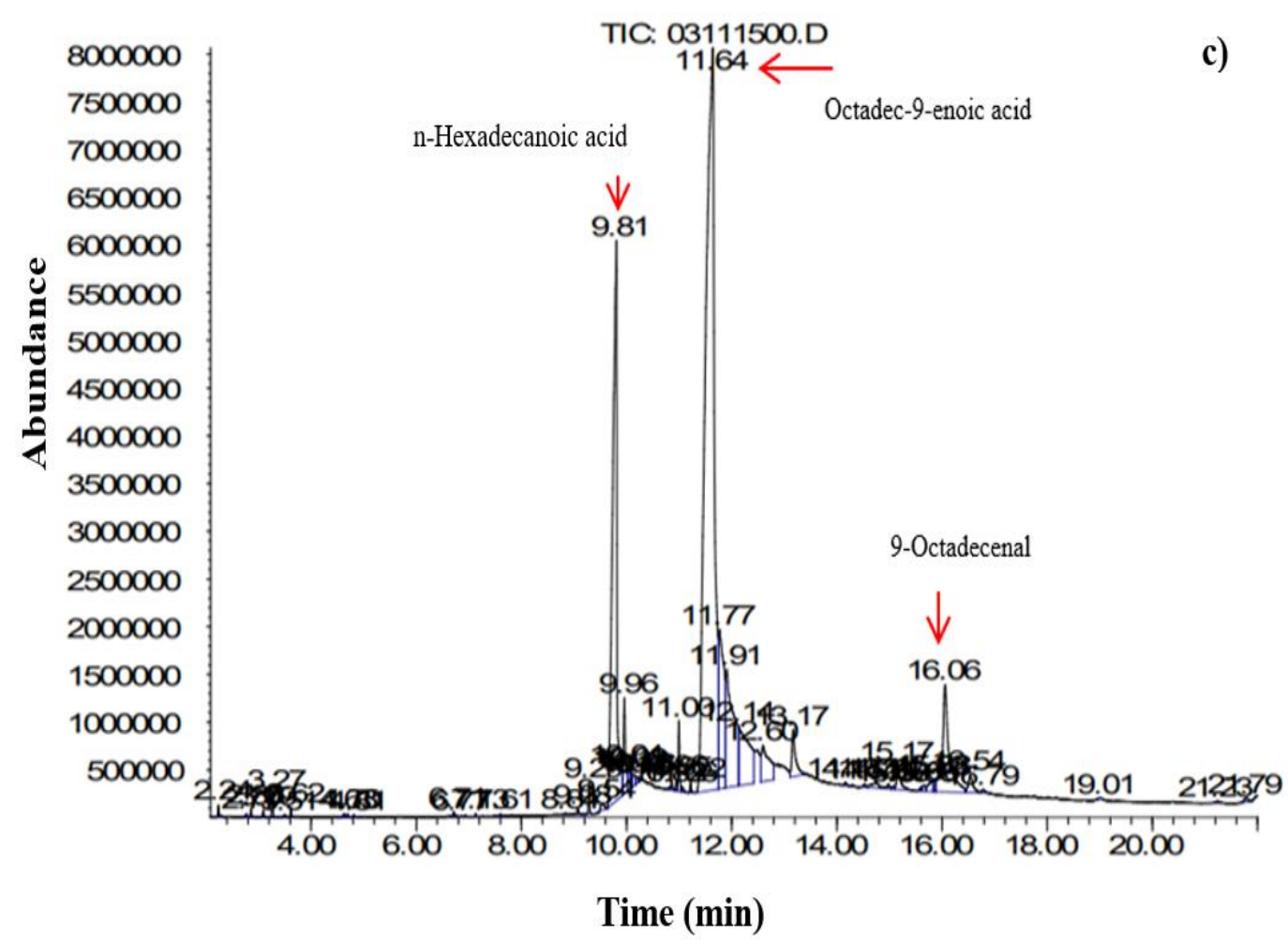

Figure 5. Gas chromatography-mass spectrometry spectra of (a) Cerbera manghas oil (Prajitno et al., 2015), and liquid products produced at $400{ }^{\circ} \mathrm{C}$ with (b) Ni-Zn(2\%)/HZSM-5 catalyst, (c) Ni-Zn(4\%)/HZSM-5 catalyst, under pressure $20 \pm 5$ bar in the batch reactor.

Table 3. Hydrocarbon composition of biofuel produced by hydrocracking at temperature of $400{ }^{\circ} \mathrm{C}$ under pressure 20 bar in batch reactor, tested GC-MS.

\begin{tabular}{|l|l|l|l|l|l|l|}
\hline \multirow{2}{*}{ Catalyst } & \multicolumn{2}{l}{ Hydrocarbon composition of biofuel (area\%) } & & \\
\hline $\mathrm{Ni}-\mathrm{Zn}(2 \%) / \mathrm{HZSM}-5$ & 0 & 0 & 0 & 0.05 & 93.09 & 6.74 \\
\hline $\mathrm{Ni}-\mathrm{Zn}(4 \%) / \mathrm{HZSM}-5$ & 0.02 & 0.06 & 0 & 0.07 & 92.99 & 6.67 \\
\hline
\end{tabular}

Gas chromatography-mass spectrometry spectra of Cerbera manghas oil and biofuel produced in the various reaction temperatures and metal loading of $5 \%$ are shown in Fig. 6 and 7, respectively. When Fig. 6 and 7 are compared, it can be seen that the compounds with retention time of $10-18 \mathrm{~min}$ in GC-MS spectra of Cerbera manghas oil disappear after reaction, as reported by a previous study (Marlinda et al., 2016). It indicated that the triglycerides containing long chain molecules were converted into short chain molecules by hydroprocessing (including cracking, deoxygenation, and isomerization reaction) with HZSM-5 catalyst, as reported by a previous study (Zheng et al., 2015). Meanwhile, the number of different compounds with retention time of 0-9 min increased, as shown in Fig. 7. The presence of $\mathrm{Ni}$ and $\mathrm{Zn}$ metals have contributed to the hydrogenation process of unsaturated fatty acids into n-paraffins. 


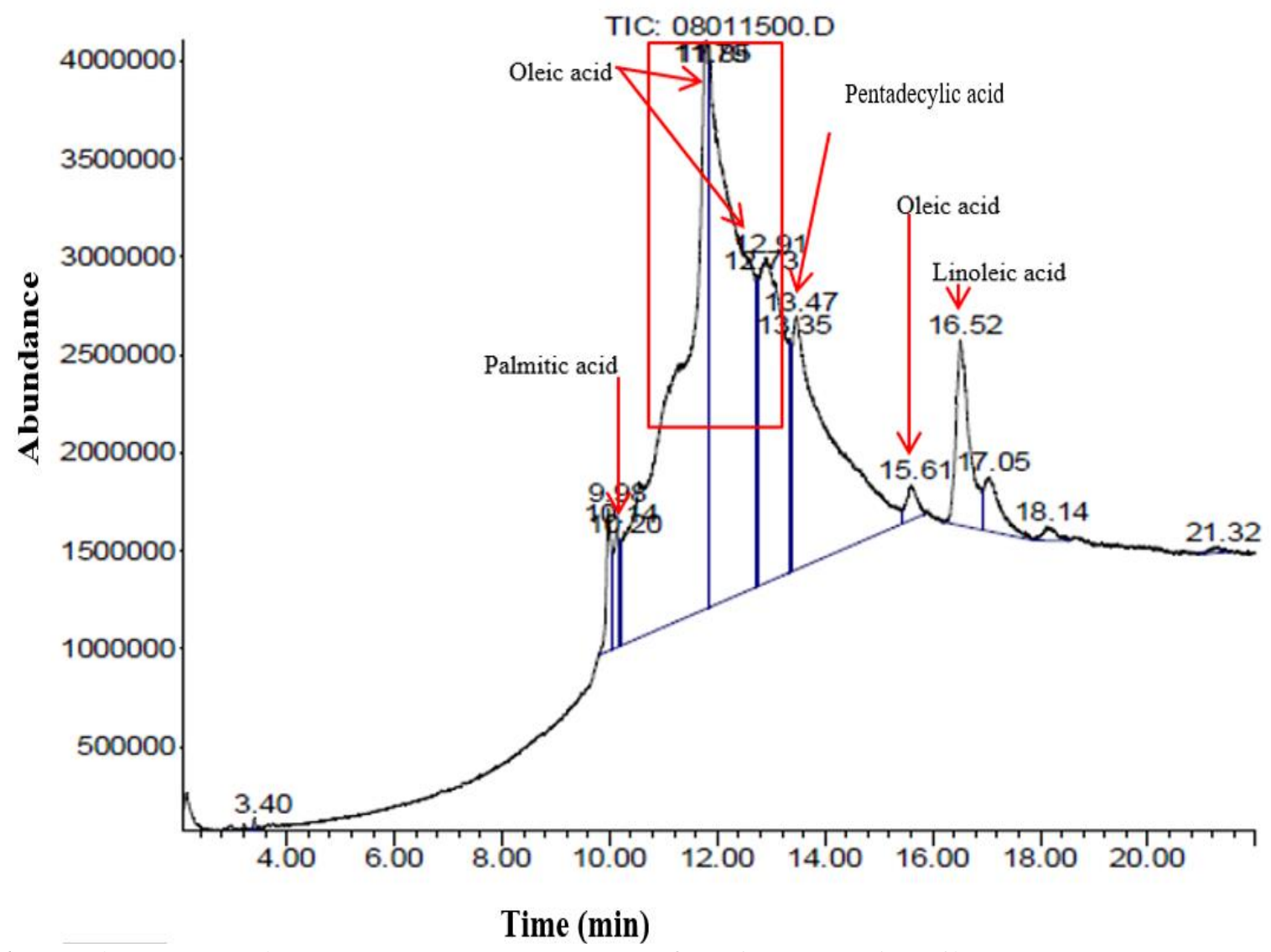

Figure 6. Gas chromatography-mass spectrometry spectra of Cerbera manghas oil.

Source: Adapted from Marlinda et al. (2016).

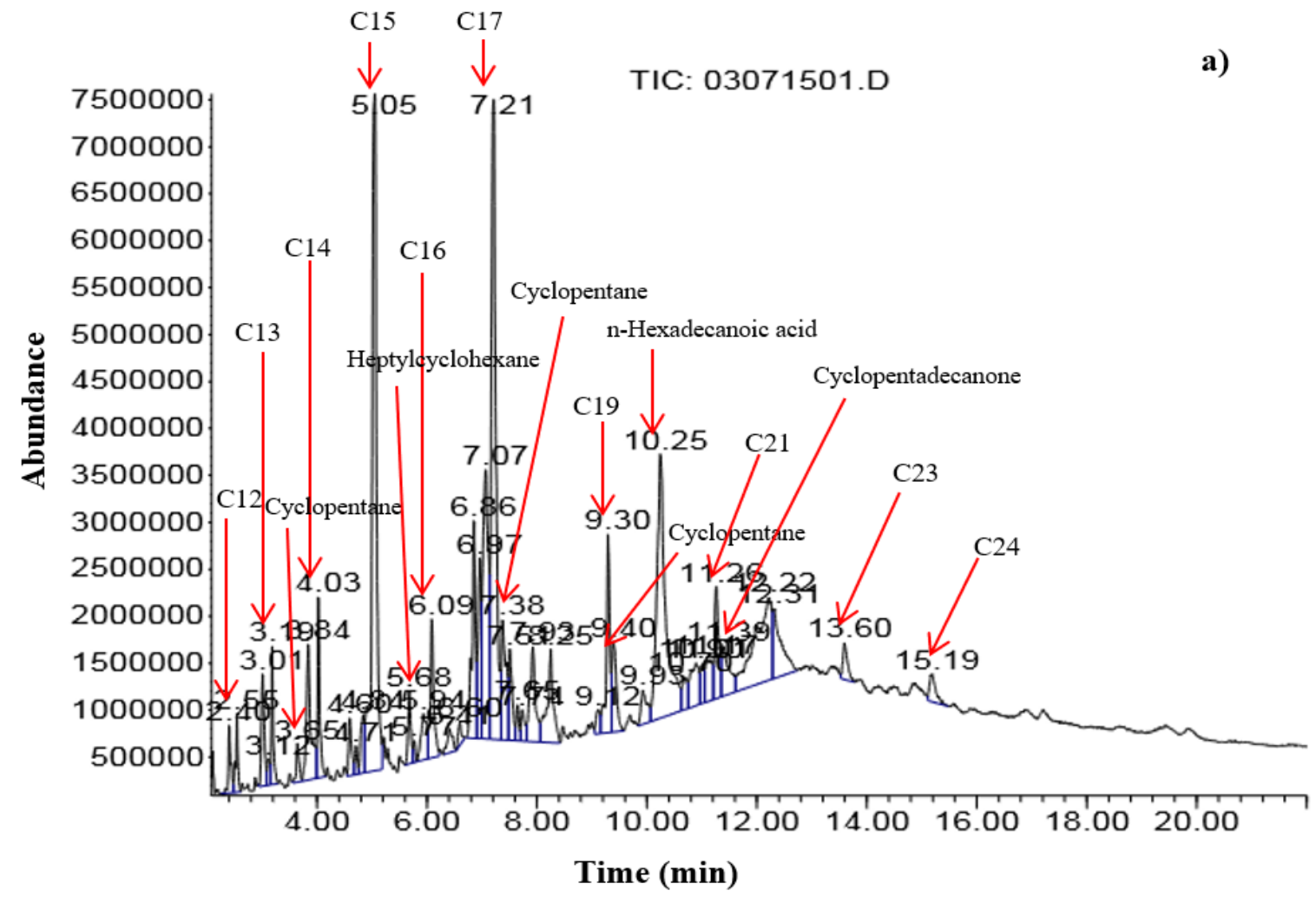



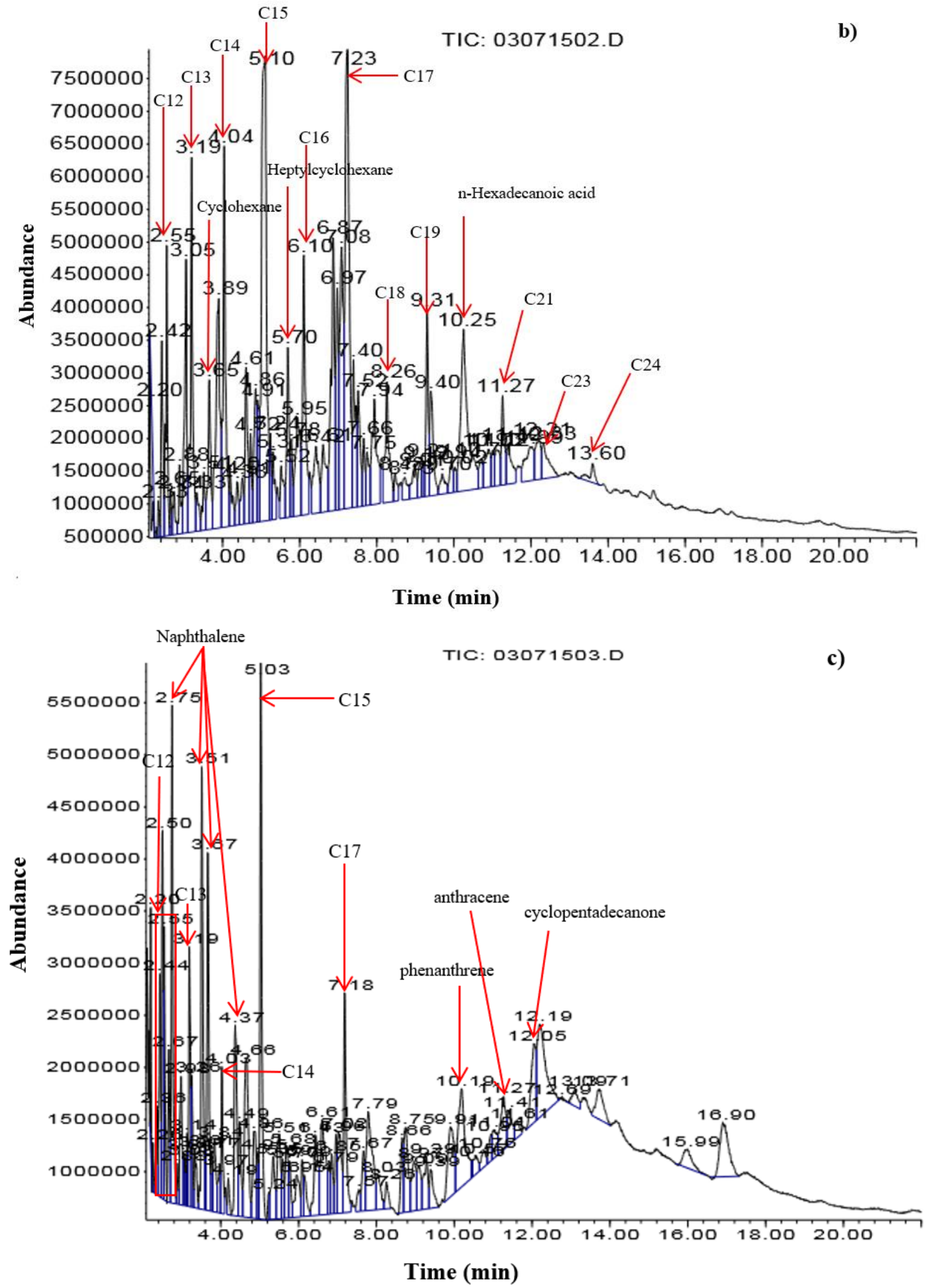


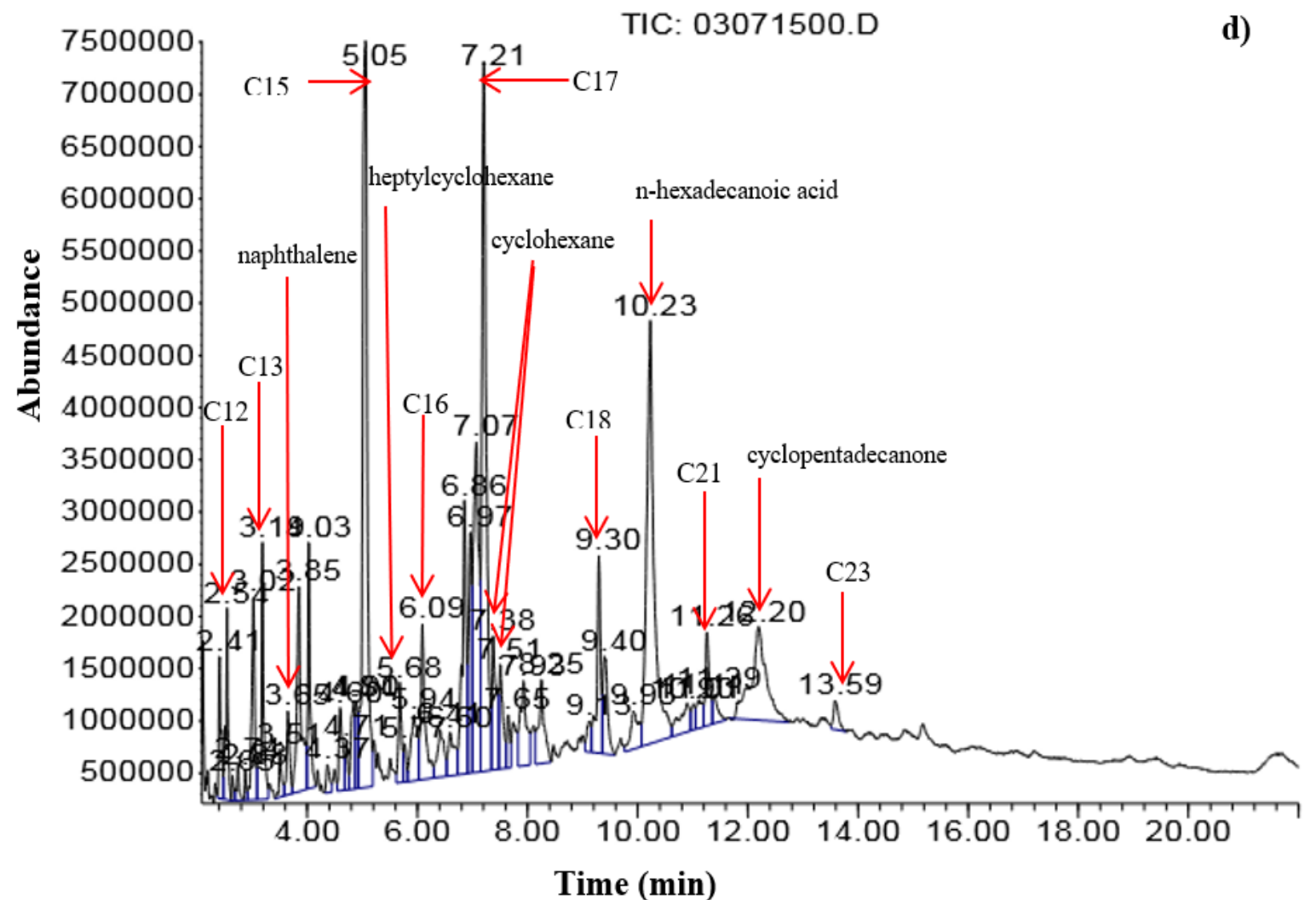

Time (min)

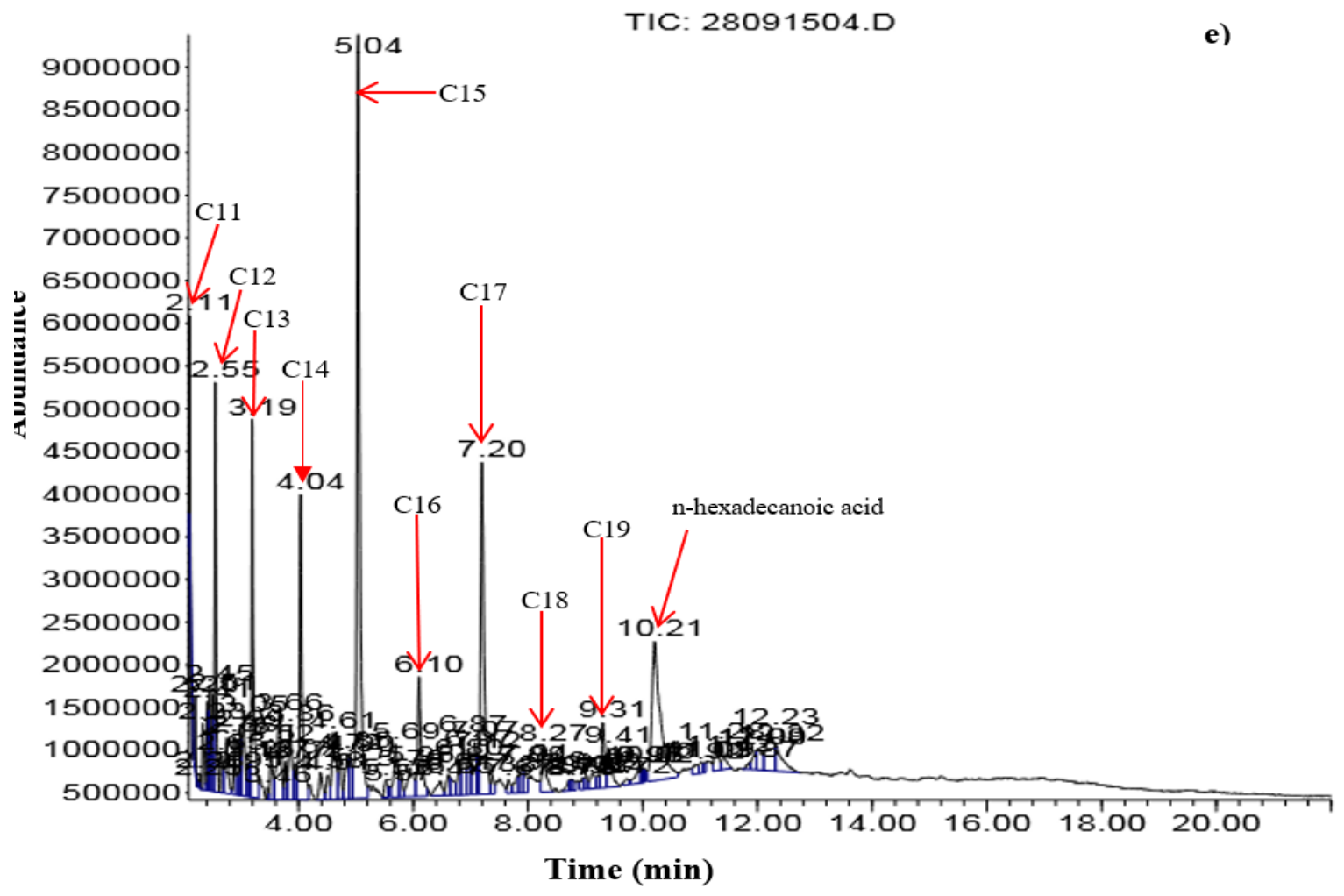




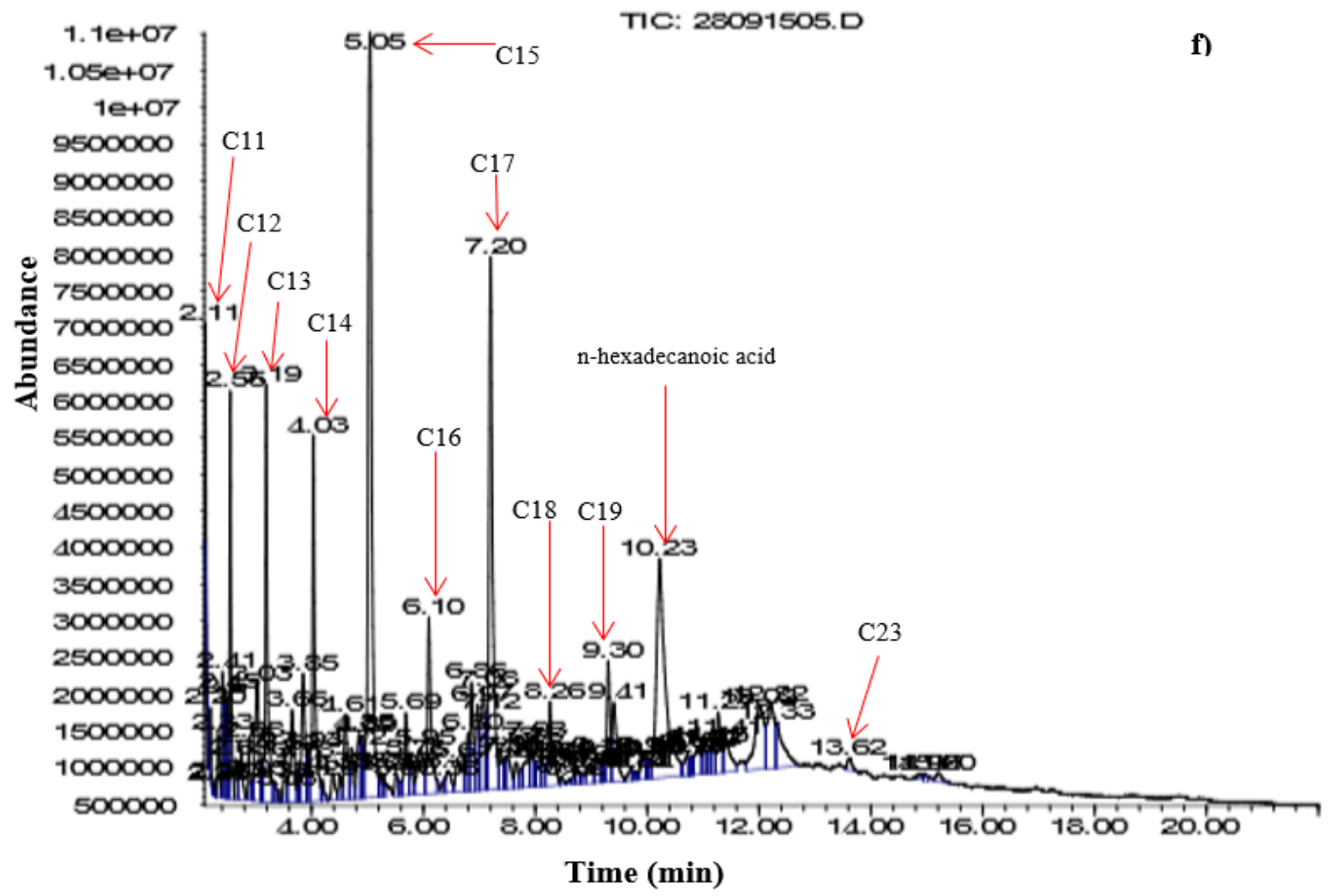

Figure 7. Gas chromatography-mass spectrometry spectra of biofuel produced at (a) $350{ }^{\circ} \mathrm{C}$, (b) $375{ }^{\circ} \mathrm{C}$, (c) $400{ }^{\circ} \mathrm{C}$ with $\mathrm{Ni}(5.43 \%)-\mathrm{Zn}(1.23 \%) / \mathrm{HZSM}-5$ catalyst, and GC-MS spectra of biofuel produced at (d) $350{ }^{\circ} \mathrm{C}$, (e) $375^{\circ} \mathrm{C}$, (f) $400{ }^{\circ} \mathrm{C}$ using $\mathrm{Ni}(5.42 \%)-\mathrm{Zn}(1.11 \%) / \mathrm{HZSM}-5$ catalyst, under pressure $20 \pm 5$ bar in the batch reactor. Saturated chain hydrocarbons (n-paraffins) have the number of carbon atom from $\mathrm{C} 12$ to $\mathrm{C} 24$.

\subsubsection{Effect of temperature on hydrocarbon composition}

Figure 8a shows that biofuel contains a different hydrocarbon composition for each temperature of hydrocracking reactions with $\mathrm{Ni}(5.43 \%)$ $\mathrm{Zn}(1.23 \%) / \mathrm{HZSM}-5$ catalyst. It can be seen that, at temperature of $350{ }^{\circ} \mathrm{C}$, biofuel contained n-paraffins of 42.03 area\%, but carboxylic acids of merely 15.48 area\%, and compounds containing oxygen of 8.69 area\%, i.e., octacosanol, were still found. Meanwhile, biofuel containing olefins of 20.31 area\% and cycloparaffins of 12.48 area\% was produced more at temperature of $375{ }^{\circ} \mathrm{C}$. On the other hand, polycyclic aromatic hydrocarbons (PAHs) and aromatic are obtained at temperature of $400{ }^{\circ} \mathrm{C}$, i.e., 21.32 and 35.47 area\%, respectively. The existence of PAHs compounds (including 1-methyl fluorene, phenanthrene, and anthracene) showed that the heating of vegetable oil was not complete. These compounds were not expected to present in biofuel. As reported by Vichaphund et al. (2015), deactivation occurred on HZSM-5 surface because of coke derived from PAHs compounds. Coke on the catalyst surface can be inhibited in the presence of hydrogen during hydrocracking reaction. However, overall, the compounds containing oxygen were still found in biofuel produced at all temperature variables. In principle, this compound should no longer exist in biofuel because the presence of oxygen atoms affects the viscosity and heating value, as reported by a previous study (Zheng et al., 2015). Furthermore, isoparaffins were not found in biofuel for each reaction temperatures. 

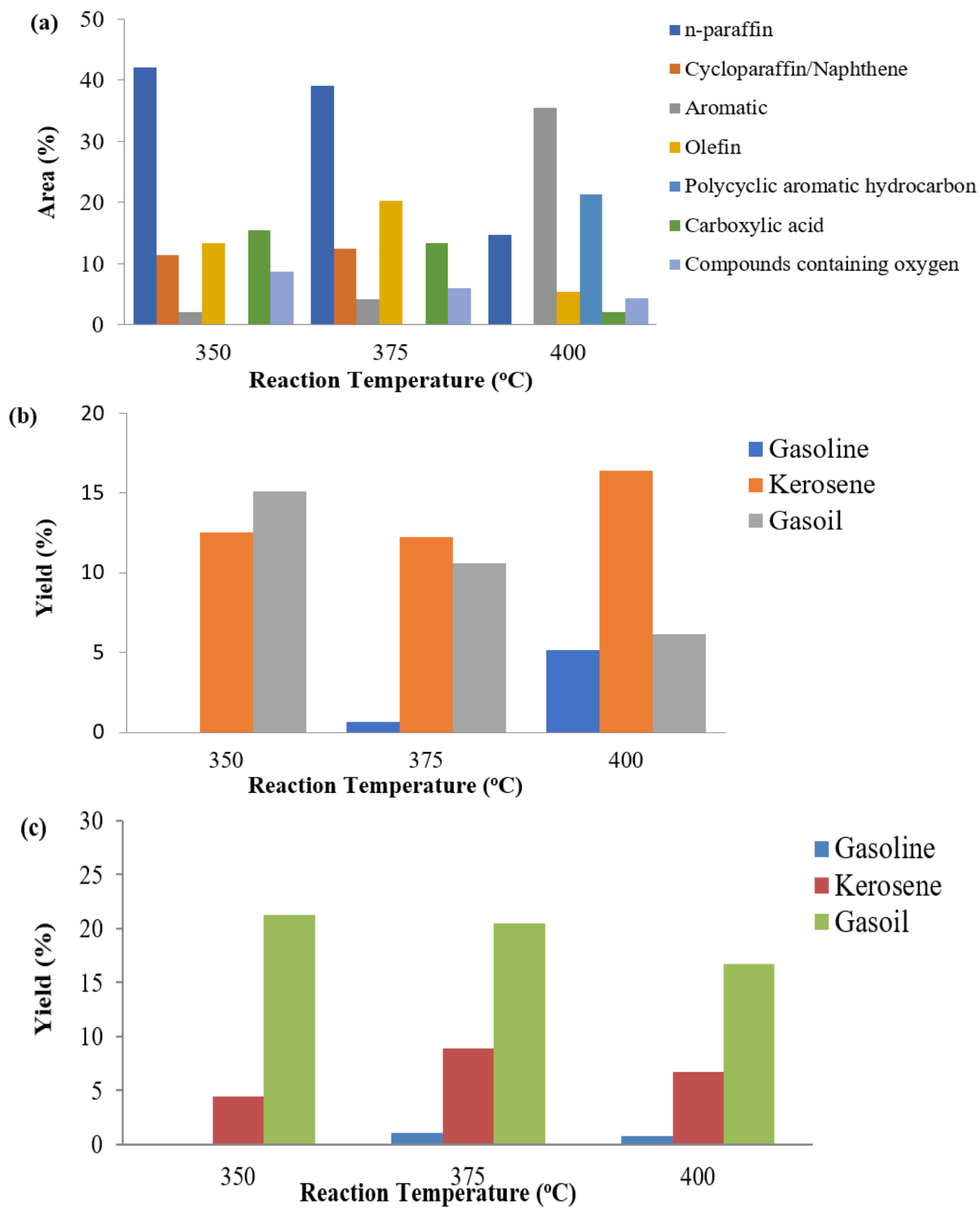

Figure 8. Effect of reaction temperature on (a) the hydrocarbon composition, (b) gasoline/kerosene/gasoil yields of liquid hydrocarbon fuel produced using $\mathrm{Ni}(5.43 \%)-\mathrm{Zn}(1.23 \%) / \mathrm{HZSM}-5$ catalyst; (c) gasoline/kerosene/gasoil yields of liquid hydrocarbon fuel produced using $\mathrm{Ni}(5.42 \%)-\mathrm{Zn}(1.11 \%) / \mathrm{HZSM}-5$ catalyst, under 20 bar in the batch reactor ("c" is elaborated by a previous study (Roesyadi et al., 2016)).

The cracking of olefins into lighter hydrocarbon compounds was shown by the decrease of olefin at temperatures from 350 to $400{ }^{\circ} \mathrm{C}$, as reported by Kim et al. (2013). On the other hand, aromatic hydrocarbon compounds, i.e., 1-methyl-2-(2-propenyl) benzene of 4.5 area\%, 1-Methylnaphthalene of 4.79 area\%, 1,6dimethylnaphthalene of 3.39 area\%, 1-ethylnaphthalene of 2.64 area\% were found at a temperature 
of $400{ }^{\circ} \mathrm{C}$. In fact, aromatics increased with the increasing reaction temperature. This suggests that aromatization reaction on olefin occurred with the presence of HZSM-5 zeolite, as reported by Pinto et al. (2014). The cycloparaffins also indicated the functionality of acidic site on HZSM-5. As stated by a previous study (Chen et al., 2016), the acidity of HZSM-5 zeolite decreased with the increase of active metal loading and $\mathrm{Si} / \mathrm{Al}$ ratio. In addition, the $\mathrm{H}_{2}$ to oil ratio would help the process of hydrogenation on olefins to n-paraffins. The determination of hydrocarbon composition and the degree of isomerization is useful to provide information to evaluate the properties of biofuel, such as cetane number (Kim et al., 2013), freezing point, flash point and viscosity (Liu et al., 2015).
Table 4 shows the components containing abundant compounds in biofuel based on group of hydrocarbons at a temperature of $350{ }^{\circ} \mathrm{C}$. The main compound of cycloparaffin was cyclohexane with branched chain resulting in hydrogenation reaction of unsaturated hydrocarbon compounds, as found by Zheng et al. (2015). The n-hexadecanoic acid was formed greatly. It was indicated that the saturation of the double bond occurred quite well. The presence of oxygen-containing compounds showed that it would be better for hydrodeoxygenation reaction to occur at temperatures above $350 \quad{ }^{\circ} \mathrm{C}$. Oxygen-containing compounds decreased from 8.69 to $4.33 \%$ at 350 and $400{ }^{\circ} \mathrm{C}$, respectively. The increase of temperature led to the increasing cracking activity.

Table 4. Several abundant compounds in each group for biofuel produced at $350{ }^{\circ} \mathrm{C}$, under 20 bar in the batch reactor* with $\mathrm{Ni}(5.43 \%)-\mathrm{Zn}(1.23 \%) / \mathrm{HZSM}-5$ catalyst.

\begin{tabular}{|c|c|c|}
\hline Compounds & Area\% & Structure \\
\hline \multicolumn{3}{|l|}{ Saturated chain hydrocarbon/n-paraffin } \\
\hline Dodecane $/ \mathrm{C}_{12} \mathrm{H}_{26}$ & 0.72 & $\mathrm{CH}_{3}$ \\
\hline Tridecane $/ \mathrm{C}_{13} \mathrm{H}_{28}$ & 1.09 & $\widehat{\mathrm{CH}_{3}}$ \\
\hline Tetradecane $/ \mathrm{C}_{14} \mathrm{H}_{30}$ & 1.78 & $\mathrm{CH}_{3}$ \\
\hline Pentadecane $/ \mathrm{C}_{15} \mathrm{H}_{32}$ & 14.14 & $\mathrm{CH}_{1}$ \\
\hline Hexadecane $/ \mathrm{C}_{16} \mathrm{H}_{34}$ & 2.06 & $\mathrm{CH}^{\mathrm{CH}_{3}}$ \\
\hline Heptadecane $/ \mathrm{C}_{17} \mathrm{H}_{34}$ & 13.06 & $\mathrm{CH}_{\mathrm{H}_{3}}$ \\
\hline Octadecane $/ \mathrm{C}_{18} \mathrm{H}_{38}$ & 2.47 & \\
\hline Nonadecane $/ \mathrm{C}_{19} \mathrm{H}_{40}$ & 3.05 & \\
\hline Heneicosane $/ \mathrm{C}_{21} \mathrm{H}_{44}$ & 2.13 & 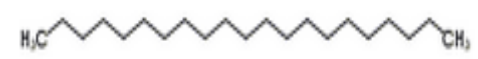 \\
\hline Tricosane & 0.76 & \\
\hline Tetracosane & 0.77 & \\
\hline \multicolumn{3}{|l|}{ Aromatic hydrocarbon } \\
\hline n-octylbenzene & 0.89 & \\
\hline (5-Methyloctyl) benzene & 1.13 & \\
\hline \multicolumn{3}{|l|}{ Cycloparaffin/Saturated naphthene } \\
\hline 1,1,3-trimethylcyclohexane & 2.36 & \\
\hline Heptylcyclohexane & 3.18 & \\
\hline 1-(cyclohexylmethyl)-2-methylcyclohexane & 0,5 & \\
\hline Cyclohexane, 1-(1,5-dimethylhex. & 0.54 & \\
\hline
\end{tabular}

Continue... 


\begin{tabular}{|c|c|c|}
\hline n-octylcyclohexane & 0.76 & \\
\hline (2-metyhlpropyl) cyclohexana & 0.48 & \\
\hline (4-octyldodecyl) cyclopentane & 1.81 & \\
\hline Cyclotetradecane & 0.22 & \\
\hline 1,7,11-trimet cyclotetradecane & 1.27 & \\
\hline Cyclopentadecane & 0.3 & \\
\hline \multicolumn{3}{|l|}{ Olefin } \\
\hline 8-Heptadecene & 9.78 & $\curvearrowright_{\mathrm{CH}_{3}}$ \\
\hline 1-Heptadecene & 2.44 & \\
\hline 9-Tricosene & 0.42 & \\
\hline 1-Hexacosene & 0.64 & \\
\hline \multicolumn{3}{|l|}{ Carboxylic acid } \\
\hline Octanoic Acid & 0.72 & \\
\hline Nonanoic acid & 1.44 & \\
\hline 9-Octadecenoic acid & 0.34 & \\
\hline n-Decanoic Acid/ $\mathrm{C}_{10} \mathrm{H}_{20} \mathrm{O}_{2}$ & 2.7 & \\
\hline n-Hexadecanoic acid & 10.28 & \\
\hline \multicolumn{3}{|l|}{ Compounds containing oxygen } \\
\hline 3-methyl-2,6-dioxo-4-hexenoic acid & 0.9 & \\
\hline Cyclopentadecanone & 1.59 & \\
\hline Octacosanol & 6.2 & $m$ \\
\hline
\end{tabular}

*Adopted from table format in literature Zheng et al. (2015).

As shown in Tab. 4, the presence of pentadecane (C15) and heptadecane (C17) indicated that HDC was the more dominant reaction pathway than HDO. Although two of these reactions allowed the formation of n-paraffin, but the $\mathrm{H}_{2}$ supplied for both reaction routes was different so that n-paraffin produced was different based on the number of carbons (Pinto et al., 2014; Sotelo-Boyás et al., 2012; Zheng et al., 2015). Hydrogenation process on Cerbera manghas oil containing tripalmitin proceeded to obtain three palmitic acids and propane. By following the route of decarboxylation and/or decarbonylation without going through the saturation of the first double bond by hydrogenation reaction, pentadecane $\left(\mathrm{C}_{15} \mathrm{H}_{32}\right)$ was immediately produced. In fact, the highest triglycerides in Cerbera manghas oil were triolein. Triolein was hydrogenated to obtain three oleic acids and propane. It still contained a double bond, so the hydrogenation process on oleic acid into stearic acid occurred. By following the route of decarboxylation and/or decarbonylation, stearic acid was converted into heptadecane $\left(\mathrm{C}_{17} \mathrm{H}_{36}\right)$. Furthermore, the aromatic compounds were produced through dehydrogenation process on olefin, i.e., the cracking and aromatization reactions as reported by Zheng et al. (2015).

With $\mathrm{Ni}(5.42 \%)-\mathrm{Zn}(1.11 \%) / H Z S M-5$ catalyst, the highest yield for n-paraffin was found at a temperature of $375{ }^{\circ} \mathrm{C}$. On the other hand, isoparaffin reaches the 
highest value of 4.58 area\% at $400{ }^{\circ} \mathrm{C}$ (Roesyadi et al., 2016). A single type of methyl isomer was obtained as isomerization product at $400{ }^{\circ} \mathrm{C}$, as shown in Tab. 5 . This is similar to the result obtained by Chen et al. (2016), who reported that the short-branched isoparaffins were formed because methyl alkanes can pass easily through the HZSM-5 pore. Ethyl isomers cannot be found because the molecular size of ethyl alkanes is larger than that of methyl alkanes. Isoparaffin increased significantly with the increasing reaction temperature because the literature (Chen et al., 2016) stated that isomerization reaction proceeded in endothermic condition.

Table 5. Several abundant compounds in each group for biofuel produced at $400{ }^{\circ} \mathrm{C}$, under 20 bar in the batch reactor*, using $\mathrm{Ni}(5.42 \%)-\mathrm{Zn}(1.11 \%) / \mathrm{HZSM}-5$ catalyst.

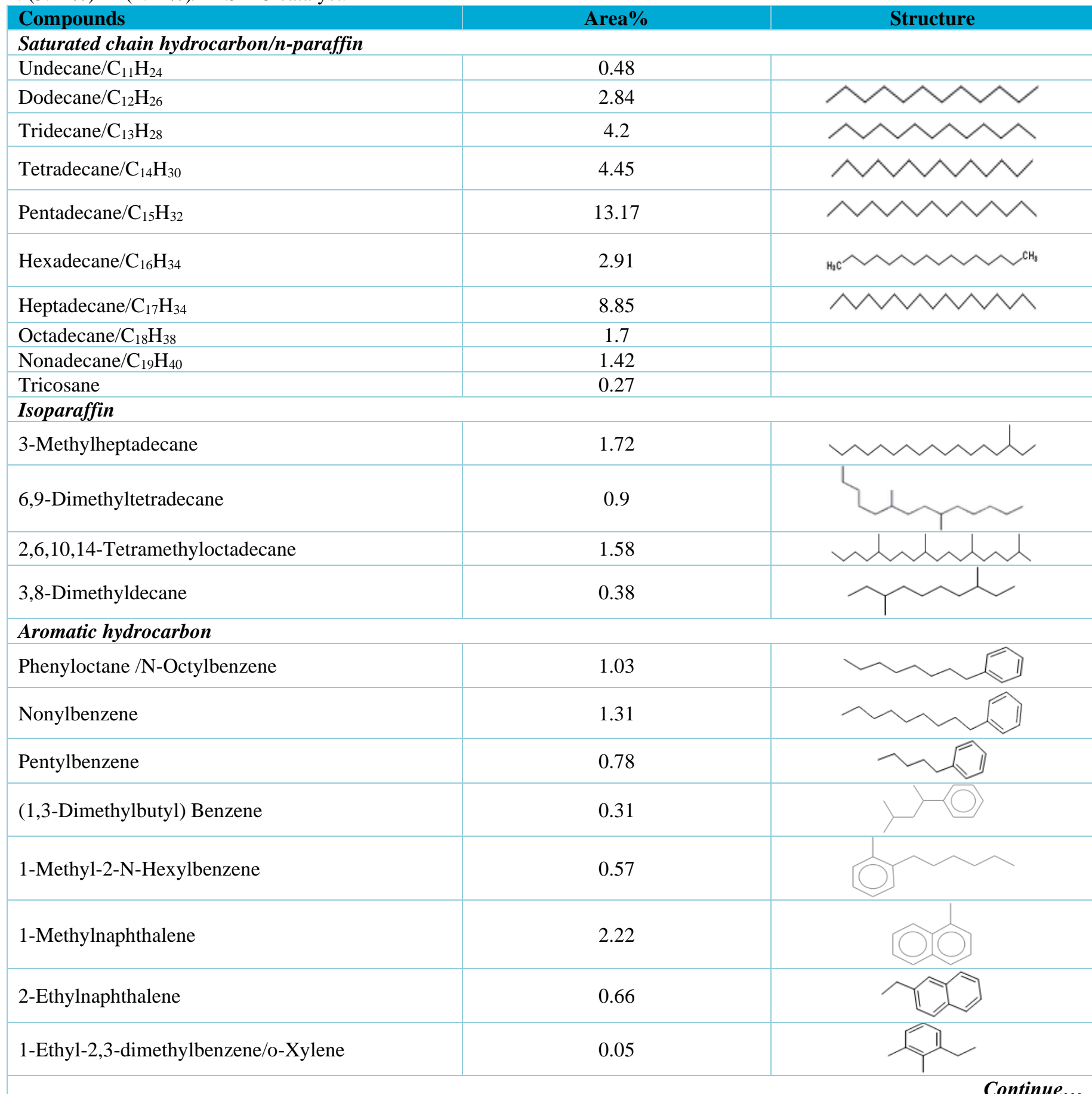




\begin{tabular}{|c|c|c|}
\hline 2-methyl-1-propenylbenzene & 0.39 & \\
\hline \multicolumn{3}{|l|}{ Cycloparaffin/Saturated naphthene } \\
\hline n-Nonylcyclohexane & 1.26 & \\
\hline $\begin{array}{l}\text { 1-(1,5-Dimethylhexyl)-4-(4-methyl pentyl) } \\
\text { cyclohexane }\end{array}$ & 3.42 & \\
\hline 1-Hexyl-3-methylcyclopentane & 0.54 & \\
\hline (4-Methylpentyl) cyclohexane & 0.46 & \\
\hline 1,2-Dicyclohexylethane & 1.35 & \\
\hline 1,1,3-Trimethylcyclohexane & 0.62 & \\
\hline 7-cyclohexyltridecane & 0.11 & \\
\hline Dicyclohexylmethane & 0.68 & \\
\hline 2,3-Dihydro-4-methyl-1H-indene & 0.7 & \\
\hline \multicolumn{3}{|l|}{ Olefin } \\
\hline 8-Heptadecene & 4.66 & \\
\hline 1-Heptadecene & 0.48 & \\
\hline 1-Docosene & 0.13 & 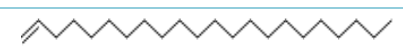 \\
\hline \multicolumn{3}{|l|}{ Carboxylic acid } \\
\hline Octanoic Acid & 0.95 & \\
\hline Nonanoic acid & 2.12 & $\mathrm{OH}$ \\
\hline n-Decanoic Acid/ $\mathrm{C}_{10} \mathrm{H}_{20} \mathrm{O}_{2}$ & 2 & \\
\hline n-Hexadecanoic acid/palmitat acid & 8.74 & \\
\hline Tetradecanoic acid & 2.09 & \\
\hline \multicolumn{3}{|l|}{ Compounds containing oxygen } \\
\hline 2-Nonadecanone & 1 & \\
\hline 2-hydroxydodecanoic acid ethyl ester & 0.35 & \\
\hline 2-Heptadecanone/Methyl pentadecyl ketone & 1.66 & \\
\hline beta-octyl acrolein & 0.7 & 今 \\
\hline 1-Oxa-2-cyclohexadecanone & 0.37 & \\
\hline
\end{tabular}

*Adopted from table format in literature Zheng et al. (2015).

With the increasing reaction temperature, aromatics increased significantly so that $\mathrm{n}$-paraffin (including $\mathrm{C} 15$ and C17) and cycloparaffins also decreased for
$\mathrm{Ni}(5.43 \%)-\mathrm{Zn}(1.23 \%) / \mathrm{HZSM}-5$ catalyst (Fig. 8a). It indicated that aromatization and cyclization reaction were favored at temperatures over $350{ }^{\circ} \mathrm{C}$ (Rocha Filho 
et al., 1993). According to Šimáček et al. (2009; 2011), aromatics also increased because of the increasing cyclization reactions rate. Tamiyakul et al. (2016) also reported that the presence of $\mathrm{Zn}^{2+}$ and $\mathrm{ZnO}$ detected in HZSM-5 was responsible for n-paraffins dehydrogenation and oxygenates decarboxylation, respectively. As a result, more aromatic yield was produced.

\subsubsection{Effect of temperature gasoline/kerosene/gasoil yields}

Gas chromatography-mass spectrometry spectra of biofuel produced was compared to the GC-MS spectra of petroleum fuel (Rasyid et al., 2015). The liquid product was identified based on hydrocarbon compounds obtained from the GC-MS analysis. Then, the identified hydrocarbon was grouped as gasoline-like hydrocarbon (C5-C9), kerosene-like hydrocarbon (C10$\mathrm{C} 13)$, and gasoil-like hydrocarbon (C14-C22), as reported by Barrón et al. (2011). Figure 8b shows gasoline/kerosene/gasoil yields for biofuel produced over $\mathrm{Ni}(5.43 \%)-\mathrm{Zn}(1.23 \%) / \mathrm{HZSM}-5$ catalyst, with reaction temperatures in the range of $350-400{ }^{\circ} \mathrm{C}$.

As confirmed by Fig. $8 \mathrm{~b}$ data, the various reaction temperatures will affect gasoil/kerosene yields. As a result, gasoil yield decreased, and kerosene yield increased with the increase of temperature. This suggests that the decline in the yield of gasoil due to hydrocracking of long chain hydrocarbons into shorter chain was random reaction mechanism, as reported in a previous study (Kim et al., 2013). It is also presented in Fig. 8b that the highest gasoline and kerosene yields were obtained at $400{ }^{\circ} \mathrm{C}$ at 5.13 and $16.42 \%$, respectively. Meanwhile, gasoil yield of $15.12 \%$ was obtained at $350{ }^{\circ} \mathrm{C}$. Gasoil decreased with the increase of reaction temperature for two type catalyst, which can be seen in Fig. 8b and c.

If Fig. 8b and c are compared based on the yield of gasoil, the characteristic performance of the $\mathrm{Ni}(5.42 \%)$ $\mathrm{Zn}(1.11 \%) / \mathrm{HZSM}-5$ catalyst is higher than that of the $\mathrm{Ni}(5.43 \%)-\mathrm{Zn}(1.23 \%) / \mathrm{HZSM}-5 \quad$ catalyst. The $\mathrm{Ni}(5.43 \%)-\mathrm{Zn}(1.23 \%) / \mathrm{HZSM}-5$ catalyst leads to the formation of gasoline and kerosene with increasing temperature. For the Ni(5.43\%)-Zn(1.23\%)/HZSM-5 catalyst, liquid hydrocarbon products in the kerosene range have been produced at $350{ }^{\circ} \mathrm{C}$ with several abundant compounds shown in Tab. 4. For Ni(5.42\%)$\mathrm{Zn}(1.11 \%) / \mathrm{HZSM}-5$, liquid hydrocarbon products in the kerosene/gasoline range were only produced at 400 ${ }^{\circ} \mathrm{C}$ with several abundant compounds, as shown in Tab. 5.
Differences in reaction temperature affect the constituent of hydrocarbons in biofuel produced. With $\mathrm{Ni}(5.43 \%)-\mathrm{Zn}(1.23 \%) / \mathrm{HZSM}-5$ catalyst, at a temperature of $350{ }^{\circ} \mathrm{C}$ kerosene contained n-paraffin, i.e., dodecane, n-octylcyclohexane, n-octylbenzene, and pentadecane, while gasoil contained hydrocarbon compound, i.e., heptadecane, octadecane, nonadecane, heneicosane, (5-Methyloctyl) benzene, heptylcyclohexane, 1-(cyclohexylmethyl)-2methylcyclohexane, and cyclopentadecane. Meanwhile, at reaction temperature of $400{ }^{\circ} \mathrm{C}$, the higher gasoline yield was obtained with composition, i.e., 1,3-diethyl-5methylbenzene, 1-methyl-2-(2-propenyl) benzene, 1,4dimethyl-dihydro-azulene, and 1-methyl-3-(1methylethyl) benzene. In principle, the presence of aromatics increases octane number in gasoline. Previously, the hydrocracking of Calophyllum inophyllum oil has been done to produce gasoline of $25.63 \%$, kerosene of $17.31 \%$ and gasoil of $38.59 \%$ with $\mathrm{CoMo}(10 \%) / \gamma-\mathrm{Al}_{2} \mathrm{O}_{3}$ catalyst at $350{ }^{\circ} \mathrm{C}$ under pressure of 30 bar (Rasyid et al., 2015).

\section{Conclusions}

The influence of the reaction temperature in hydrocracking on Cerbera manghas oil into biofuel with a catalyst Ni-Zn/HZSM-5 has been studied. The amount of n-paraffin decreased with the increasing temperature and followed by the increase of cycloparaffins and aromatics. This increasing reaction temperature led to an increase in the activity of cracking on a longer carbon chain molecule into a shorter carbon chain molecule. With $\mathrm{Ni}(5.43 \%)-\mathrm{Zn}(1.23 \%) / \mathrm{HZSM}-5$ catalyst, highest kerosene was obtained at a temperature of $400{ }^{\circ} \mathrm{C}$. At the same temperature, the higher isoparaffins contained the short-branched isoalkanes in gasoil were detected when the $\mathrm{Ni}(5.42 \%)$ Zn(1.11\%)/HZSM-5 catalyst was used. Therefore, reaction routes during hydrocracking are influenced by the reaction temperature and catalyst composition of $\mathrm{Ni}-\mathrm{Zn} / \mathrm{HZSM}-5$, which provides acid function and metal function.

\section{Authors' contribution}

Conceptualization: Marlinda, L.; Danawati, H. P.

Data curation: Marlinda, L.

Formal Analysis: Marlinda, L.

Funding acquisition: Marlinda, L.; Danawati, H. P. Investigation: Marlinda, L.; Danawati, H. P.; Roesyadi, A.; Gunardi, I.; Mirzayanti, Y. W.; Al Muttaqii, M.; Budianto, A. 
Methodology: Marlinda, L.; Danawati, H. P.; Roesyadi, A.; Al Muttaqii, M.

Project administration: Marlinda, L.; Budianto, A.

Resources: Roesyadi, A.

Software: Not applicable

Supervision: Danawati, H. P.; Roesyadi, A.;

Gunardi, I.

Validation: Danawati, H. P.; Roesyadi, A.; Gunardi, I.; Budianto, A.

Visualization: Marlinda, L.

Writing - original draft: Marlinda, L.

Writing - review \& editing: Marlinda, L.; $\mathrm{Al}$ Muttaqii, M.; Mirzayanti, Y. W.

\section{Data availability statement}

All data sets were generated or analyzed in the current study.

\section{Funding}

DIPA-PNBP LPPM Faculty of Science and Technology, Lecturer Research Scheme, University of Jambi Fiscal Year 2019 Number: SP-DIPA042.01.2.400950/2019 dated December 5 2018, according to the Research Contract Agreement Number: B/628/UN21.18/ PT.01.03/2019 Date 07 May 2019.

\section{Acknowledgments}

We thank to Chemical Reaction Engineering Laboratory, Department of Chemical Engineering, Sepuluh Nopember Institute of Technology for all the support, resources, and mentorship they provided. We are also sincerely grateful to Muhammad Iqbal, Victor Purnomo, and Ricco Aditya Setiyo Wicaksono (the research team member) for their contribution in this work. Finally, we would like to thank the University of Jambi, for funding this project.

\section{References}

Arun, N.; Sharma, R. V.; Dalai, A. K. Green diesel synthesis by hydrodeoxygenation of bio-based feedstocks: Strategies for catalyst design and development. Renew. Sustain. Energy Rev. 2015, 48, 240-255. https://doi.org/10.1016/j.rser.2015.03.074

Ayodele, O. B.; Farouk, H. U.; Mohammed, J.; Uemura, Y.; Daud W. M. A. W. Hydrodeoxygenation of oleic acid into nand iso-paraffin biofuel using zeolite supported fluor-oxalate modified molybdenum catalyst: Kinetics study. J. Taiwan
Inst. Chem. Eng. 2015, 50, 142-152. https://doi.org/10.1016/j.jtice.2014.12.014

Barrón, C. A. E.; Melo-Banda, J. A.; Dominguez, J. M. E.; Hernández, M. E.; Silva, R. R.; Reyes, T. A. I.; Meraz, M. M. A. Catalytic hydrocracking of vegetable oil for agrofuels production using $\mathrm{Ni}-\mathrm{Mo}, \mathrm{Ni}-\mathrm{W}, \mathrm{Pt}$ and TFA catalysts supported on SBA-15. Catal. Today 2011, 166 (1), 102-110. https://doi.org/10.1016/j.cattod.2011.01.026

Bezergianni, S.; Dimitriadis, A.; Meletidis, G. Effectiveness of CoMo and NiMo catalysts on co-hydroprocessing of heavy atmospheric gas oil-waste cooking oil mixtures. Fuel 2014, 125 , 129-136.

https://doi.org/10.1016/j.fuel.2014.02.010

Bockisch, M. Fats and Oils Handbook; AOCS Press, 1998. https://doi.org/10.1016/B978-0-9818936-0-0.50003-2

Budianto, A.; Prajitno, D. H.; Budhikarjono, K. Biofuel production from candlenut oil using catalytic cracking process with Zn/HZSM-5 catalyst. ARPN J. Eng. Appl. Sci. 2014a, 9 (11), 2121-2124.

Budianto, A.; Danawati H. P.; Roesyadi, A.; Budhikarjono, K. HZSM-5 catalyst for cracking palm oil to biodiesel: A Comparative study with and without $\mathrm{Pt}$ and $\mathrm{Pd}$ impregnation. Scientific Study \& Research: Chemistry \& Chemical Engineering, Biotechnology, Food Industry 2014b, 15 (1): 81-90.

Carlier, J.; Guitton, J.; Bévalot, F.; Fanton, L.; Gaillard. Y. The principal toxic glycosidic steroids in Cerbera manghas L. seeds: Identification of cerberin, neriifolin, tanghinin and deacetyltanghinin by UHPLC-HRMS/MS, quantification by UHPLC-PDA-MS. J. Chromatogr. B 2014, 962, 1-8. https://doi.org/10.1016/j.jchromb.2014.05.014

Chen, X.; Dong, M.; Niu, X.; Wang, K.; Chen, G.; Fan, W.; Wang, J.; Qin, Z. Influence of Zn species in HZSM-5 on ethylene aromatization. Chin. J. Catal. 2015, 36 (6), 880 888. https://doi.org/10.1016/S1872-2067(14)60289-8

Chen, L.; Li, H.; Fu, J.; Miao, C.; Lv, P.; Yuan, Z. Catalytic hydroprocessing of fatty acid methyl esters to renewable alkane fuels over Ni/HZSM-5 catalyst. Catal. Today 2016, 259 (Part 2), 266-276. https://doi.org/10.1016/j.cattod.2015.08.023

Chuah, L. F.; Yusup, S.; Aziz, A. R. A.; Klemeš, J. J.; Bokhari, A.; Abdullah, M. Z. Influence of fatty acids content in non-edible oil for biodiesel properties. Clean Techn. Environ. Policy 2016, 18, 473-482. https://doi.org/10.1007/s10098-015-1022-x

Dwivedi, G.; Sharma, M. P. Application of Box-Behnken design in optimization of biodiesel yield from Pongamia oil and its stability analysis. Fuel 2015, 145, 256-262. https://doi.org/10.1016/j.jiec.2012.03.019 
Haber, J.; Block, J. H.; Delmon, B. Manual of methods and procedures for catalyst characterization. Pure \& Appl. Chem. 1995, 67 (Nos 8/9), $1257-1306$. https://doi.org/10.1351/pac199567081257

Hao, K.; Shen, B.; Wang, Y.; Ren, J. Influence of combined alkaline treatment and Fe-Ti-loading modification on ZSM5 zeolite and its catalytic performance in light olefin production. J. Ind. Eng. Chem. 2012, 18 (5), 1736-1740. https://doi.org/10.1016/j.jiec.2012.03.019

Isahak, W. N. R. W.; Hisham, M. W. M.; Yarmo, M. A.; Hin, T.-y. Y. A review on bio-oil production from biomass by using pyrolysis method. Renew. Sustain. Energy Rev. 2012, $16 \quad$ (8), 5910-5923. https://doi.org/10.1016/j.rser.2012.05.039

Ishihara, A.; Fukui, N.; Nasu, H.; Hashimoto, T. Hydrocracking of soybean oil using zeolite-alumina composite supported NiMo catalyst. Fuel 2014, 134, 611617. https://doi.org/10.1016/j.fuel.2014.06.004

Kim, S. K.; Brand, S.; Lee, H.-s.; Kim, Y.; Kim, J. Production of renewable diesel by hydrotreatment of soybean oil: Effect of reaction parameters. Chem. Eng. J. 2013, 228, 114-123. https://doi.org/10.1016/j.cej.2013.04.095

Li, L.; Quan, K.; Xu, J.; Liu, F.; Liu, S.; Yu, S.; Xie, C.; Zhang, B.; Ge, X. Liquid hydrocarbon fuels from catalytic cracking of rubber seed oil using USY as catalyst. Fuel 2014, 123 ,

189-193.

https://doi.org/10.1016/j.fuel.2014.01.049

Liu, S.; Zhu, Q.; Guan, Q.; He, L.; Li, W. Bio-aviation fuel production from hydroprocessing castor oil promoted by the nickel-based bifunctional catalysts. Bioresour. Technol. 2015, 183, 93-100. https://doi.org/10.1016/j.biortech.2015.02.056

Lu, Q.; Li, W.-Z.; Zhu, X.-F. Overview of fuel properties of biomass fast pyrolysis oils. Energy Convers. Manag. 2009, $50 \quad$ (5), 1376-1383. https://doi.org/10.1016/j.enconman.2009.01.001

Marlinda, L.; Al-Muttaqii, M.; Roesyadi, A.; Prajitino, D. H. Production of biofuel by hydrocracking of Cerbera Manghas oil using Co-Ni/HZSM-5 catalyst: Effect of reaction temperature. J. Pure App. Chem. Res. 2016, 5 (3), 189-195. https://doi.org/10.21776/ub.jpacr.2016.005.03.254

Niu, X.; Gao, J.; Miao, Q.; Dong, M.; Wang, G.; Fan, W.; Qin, Z.; Wang, J. Influence of preparation method on the performance of Zn-containing HZSM-5 catalysts in methanol-to-aromatics. Microporous Mesoporous Mater. 2014, 197, 252-261.
Pinto, F.; Martins, S.; Gonçalves, M.; Costa, P.; Gulyurtlu, I.; Alves, A.; Mendes, B. Hydrogenation of rapeseed oil for production of liquid bio-chemicals. Appl. Energy 2013, 102, 272-282. https://doi.org/10.1016/j.apenergy.2012.04.008

Pinto, F.; Varela, F. T.; Gonçalves, M.; André Neto, R.; Costa, P.; Mendes, B. Production of bio-hydrocarbons by hydrotreating of pomace oil. Fuel 2014, 116, 84-93. https://doi.org/10.1016/j.fuel.2013.07.116

Prajitno, D. H.; Roesyadi, A.; Budianto, A.; Iqbal, M.; Purnomo, V. Modification of Ni-Zn/HZSM-5 double promoted catalyst for biofuel production from Cerbera manghas oil. In Green Chemistry Section 1: Material Chemistry, Proceedings of the $9^{\text {th }}$ Joint Conference on Chemistry, Semarang, Indonesia, November 12-13, 2014; Prajitno, D. H.; Roesyadi, A.; Budianto, A.; Iqbal, M.; Purnomo, V., Eds.; Diponegoro University: Semarang, 2015; pp 25-28.

Rasyid, R.; Prihartantyo, A.; Mahfud, M.; Roesyadi, A. Hydrocracking of Calophyllum inophyllum oil with nonsulfide CoMo catalysts. Bull. Chem. React. Eng. Catal. 2015, $10 \quad$ (1), 61-69. https://doi.org/10.9767/bcrec.10.1.6597.61-69

Rocha Filho, G. N.; Brodzki, D.; Djéga-Mariadassou, G. Formation of alkanes alkylcykloalkanes and alkylbenzenes during the catalytic hydrocracking of vegetable oils. Fuel 1993, 72 (4), 543-549. https://doi.org/10.1016/00162361(93)90114-H

Roesyadi, A.; Hariprajitno, D.; Nurjannah, N.; Savitri, S. D. HZSM-5 Catalyst for cracking palm oil to gasoline: A comparative study with and without impregnation. Bull. Chem. React. Eng. Catal. 2013, 7 (3), 185-190. https://doi.org/10.9767/bcrec.7.3.4045.185-190

Roesyadi, A. Pembuatan Biofuel dari Minyak Nabati; PT. Revka Petra Media, 2016.

Roesyadi, A.; Budianto, A.; Prajitno, D. H.; Gunardi, I.; Marlinda, L. Metode Pembuatan Katalis Ni-Zn/HZSM-5 untuk Produksi Biofuel dari Minyak Bintaro (Cerbera Manghas Oil). ID, P00201607714, 2016. https://pdkiindonesia.dgip.go.id/detail/P00201607714?type=patent\&key word=bintaro (accessed 2021-12-19).

Romero, M. D.; Calles, J. A.; Rodríguez, A.; Cabanelas, J. C. The influence of calcination treatment over bifunctional Ni/HZSM-5 catalysts. Ind. Eng. Chem. Res. 1998, 37 (10), 3846-3852. https://doi.org/10.1021/ie980143i

Romero, M.; Pizzi, A.; Toscano, G.; Casazza, A. A.; Busca, G.; Bosio, B.; Arato, E. Preliminary experimental study on biofuel production by deoxygenation of Jatropha oil. Fuel Process. Technol. 2015, 137, 31-37. https://doi.org/10.1016/j.fuproc.2015.04.002 
Santillan-Jimenez E.; Crocker, M. Catalytic deoxygenation of fatty acids and their derivatives to hydrocarbon fuels via decarboxylation/decarbonylation. J. Chem. Technol. Biotechnol. $\quad$ 2012, 87 (8), $1041-1050$. https://doi.org/10.1002/jctb.3775

Sartipi, S.; Parashar, K.; Valero-Romero, M. J.; Santos, V. P.; van der Linden, B.; Makkee, M.; Kapteijn, F.; Gascon, J. Hierarchical H-ZSM-5-supported cobalt for direct synthesis of gasoline-range hydrocarbon from syngas: Advantages, limitation, and mechanistic insight. J. Catal. 2013, 305, 179190. https://doi.org/10.1016/j.jcat.2013.05.012

Silva, V. T.; Sousa, L. A. Catalytic upgrading of fats and vegetable oils for the production of fuels. In The role of catalysis for the sustainable production of bio-fuels and biochemicals; Elsevier Science; 2013, pp 67-92. https://doi.org/10.1016/B978-0-444-56330-9.00003-6

Šimáček, P.; Kubička, D.; Šebor, G.; Pospíšil, M. Hydroprocessed rapeseed oil as a source of hydrocarbonbased biodiesel. Fuel 2009, 88 (3), 456-460. https://doi.org/10.1016/j.fuel.2008.10.022

Šimáček, P.; Kubička, D.; Kubičková, I.; Homola, F.; Pospíšil, M.; Chudoba, J. Premium quality renewable diesel fuel by hydroprocessing of sunflower oil. Fuel 2011, 90, 2473-2479. https://doi.org/10.1016/j.fuel.2011.03.013

Sotelo-Boyás, R.; Trejo-Zárraga, F.; Hernández-Loyo, F. J. Hydroconversion of triglycerides into green liquid fuels. In Hydrogenation; IntechOpen, 2012; pp 187-216. https://doi.org/10.5772/48710

Tamiyakul, S.; Anutamjarikun, S.; Jongpatiwut, S. The effect of Ga and Zn over HZSM-5 on the transformation of palm fatty acid distillate (PFAD) to aromatics. Catal. Commun. 2016, 74, 49-54. https://doi.org/10.1016/j.catcom.2015.11.002

Vichaphund, S.; Aht-ong, D.; Sricharoenchaikul, V.; Atong, D. Production of aromatic compounds from catalytic fast pyrolysis of Jatropha residues using metal/HZSM-5 prepared by ion-exchange and impregnation methods. Renew. Energy 2015, 79, 28-37. https://doi.org/10.1016/j.renene.2014.10.013

Vitale, G.; Molero, H.; Hernandez, E.; Aquino, S.; Birss, V.; Pereira-Almao, P. One-pot preparation and characterization of bifunctional Ni-containing ZSM-5 catalyst. Appl. Catal. A: Gen. 2013, 452, 75-87. https://doi.org/10.1016/j.apcata.2012.11.026

Wang, S.; Yin, Q.; Guo, J.; Ru, B.; Zhu, L. Improved Fischer-Tropsch synthesis for gasoline over Ru, Ni promoted Co/HZSM-5 catalyst. Fuel 2013, 108, 597-603. https://doi.org/10.1016/j.fuel.2013.02.021
Wang, C.; Liu, Q.; Song, J.; Li, W.; Li, P.; Xu, R.; Ma, H.; Tian, Z. High quality diesel-range alkanes production via a single-step hydrotreatment of vegetable oil over $\mathrm{Ni} /$ zeolite catalyst. Catal. Today 2014, 234, 153-160. https://doi.org/10.1016/j.cattod.2014.02.011

Wu, L.; Guo, S.; Wang, C.; Yang Z. Production of alkanes $\left(\mathrm{C}_{7}-\mathrm{C}_{29}\right)$ from different part of poplar tree via direct deoxyliquefaction. Bioresour. Technol. 2009, 100 (6), 2069-2076. https://doi.org/10.1016/j.biortech.2008.10.024

Zhang, H.; Lin, H.; Zheng, Y. The role of cobalt and nickel in deoxygenation of vegetable oils. Appl. Catal. B: Environ. 2014, 160-161,

415-422. https://doi.org/10.1016/j.apcatb.2014.05.043

Zheng, X.; Chang, J.; Fu, Y. One-pot catalytic hydrocracking of diesel distillate and residual oil fractions obtained from bio-oil to gasoline-range hydrocarbon fuel. $\begin{array}{llll}\text { Fuel } & \mathbf{2 0 1 5}, & 157, & 107-114 .\end{array}$ https://doi.org/10.1016/j.fuel.2015.05.002 